\title{
Elemental and biomarker characteristics in a Pleistocene aquifer vulnerable to arsenic contamination in the Bengal Delta Plain, India
}

\author{
Devanita Ghosh, Joyanto Routh, Mårten Dario and Punyasloke Bhadury
}

\section{Linköping University Post Print}

\section{Tweet}

N.B.: When citing this work, cite the original article.

Original Publication:

Devanita Ghosh, Joyanto Routh, Mårten Dario and Punyasloke Bhadury, Elemental and biomarker characteristics in a Pleistocene aquifer vulnerable to arsenic contamination in the Bengal Delta Plain, India, 2015, Applied Geochemistry, (61), 87-98.

http://dx.doi.org/10.1016/j.apgeochem.2015.05.007

Copyright: Elsevier

\section{http://www.elsevier.com/}

Postprint available at: Linköping University Electronic Press

http://urn.kb.se/resolve?urn=urn:nbn:se:liu:diva-122048

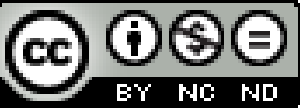


Elemental and Biomarker characteristics in a Pleistocene aquifer vulnerable to arsenic contamination in the Bengal Delta Plain, India

3

4 Devanita Ghosh $^{\mathrm{a}, \mathrm{b}}$, Joyanto Routh ${ }^{\mathrm{b}, 1}$, Mårten Dario ${ }^{\mathrm{b}}$, Punyasloke Bhadury 5

aDepartment of Biological Sciences, Indian Institute of Science Education and Research Kolkata, Mohanpur Campus, Nadia 741252, West Bengal, India

8 bDepartment of Thematic Studies - Environmental Change, Linköping University, 58183

9 Linköping, Sweden

\section{Abstract} An elevated level of arsenic (As) in the Indo-Gangetic delta plain aquifers has been reported since the 1990s. Organic matter (OM) present in groundwater and aquifer sediments sustains the microbial communities in these aquifers. In this study, during installation of a drinking water well, 26 sediment intervals of $6 \mathrm{~m}$ each were retrieved up till $156 \mathrm{~m}$ from a Pleistocene brown sand aquifer (BSA). The aquifer sediments consist of medium to coarse sand except the surface sediments and those at bottom, which have high clay and slit content. Various geochemical analyses in the sediment samples include sequential extraction of trace metals and total extractable lipids. Arsenic (As) concentration in sediments range from 2 to $21 \mathrm{mg} / \mathrm{kg}$ and indicate a strong correlation with grain size. Arsenic is mostly associated with crystalline oxides

21 and silicate-rich minerals. Arsenic shows significant correlation with Fe in different geochemical

22 fractions and suggests presence of pyrite bound As-bearing minerals in these sediments. The 23 sediments indicate diagnostic biomarkers such as $n$-alkanoic acids, $n$-alkanes, $n$-alkanols and 24 sterols. The presence of these compounds is associated with terrigenous sources derived from vascular plants and microbial cell wall. The inference is supported by various diagnostic lipid ratios. The biomarkers are abundant in surface and deeper layers, which have high clay and silt

27 content. The BSA sediments indicate preferential preservation of $n$-alkanes over other

\footnotetext{
${ }^{1}$ Corresponding author: joyanto.routh@liu.se, Tel : +4613282272, Fax: +4613133630
}

TEMA - Environmental Change, Linköping University, 58183 Linköping, Sweden 
functionalized compounds, which are more reactive and subject to degradation. The thick clay lens at 132 to $156 \mathrm{~m}$ contains visible plant fragments, and OM in this layer indicates preferential preservation of the organic carbon perhaps due to the absence of microbial communities that degrade these compounds, and mobilize As into groundwater.

Key words: Arsenic, Pleistocene aquifers, Metals, Biomarkers, Microbes

\section{Introduction}

High arsenic (As) concentration in groundwater and its exposure to a large number of people in Southeast Asia has caused long term endemic health problems (Bhattacharya et al., 2002). This issue has received significant attention since the 1990s (Guha et al., 1988). The Bengal Delta Plain (BDP) in northeastern India and Bangladesh is one of these regions, which is most affected by the high As concentrations in drinking water. These deltaic plains are located in the river basins of Ganges, Brahmaputra and Meghna rivers, and extend over ca. $2 \times 10^{6} \mathrm{~km}^{2}$ (Curray and Moore, 1974).

Researchers have proposed many models for explaining the mechanism of As mobilization and explaining its source in these aquifers. The reductive dissolution of geogenic iron Fe(III) oxyhydroxide minerals bearing As is widely accepted. This process underlines the complex biogeochemical processes which influence As mobilization in BDP aquifers (Bhattacharya et al., 1997; Nickson et al., 1998, 2000; Harvey et al., 2002; McArthur et al., 2004). The reductive dissolution Fe(III) oxy-hydroxide minerals is coupled with microbial utilization of organic matter (OM) as electron donor during respiration (Nickson et al., 2000; Berg et al., 2001; Harvey et al., 2002; Islam et al., 2004). Along with increase in As concentrations, the process results in increase of alkalinity and dissolved iron in groundwater (Nickson et al., 2000). Consistent with this, many studies have indicated that biological processes play a critical role by changing redox conditions or converting the As species (from $\mathrm{As}(\mathrm{V})$ to $\mathrm{As}(\mathrm{III})$ ), and impacting its mobilization in surface and groundwater (Oremland and Stolz, 2003, 2005; Quemeneur et al., 2008). 
Recent studies have demonstrated that sedimentary and dissolved organic matter (OM) in BDP

59 aquifers utilized by in situ microbes are key factors controlling the release of As (Farooq et al., 2010; Postma et al., 2007; Rowland et al., 2006, 2007; Ghosh et al., in review).Various external and internal sources of OM have been proposed by researchers, which contribute to the OM pool in sedimentary aquifers. Anthropogenic sources of OM can be surface derived inputs (McArthur et al., 2001; Lawson et al., 2013), whereas autochthonous sources include relatively recalcitrant naturally derived OM, which are primarily found in organic rich clayey-peat lenses in the BDP aquifers (Umitsu, 1993; Goodbred and Kuehl, 2000; McArthur et al., 2004; Anwar et al., 2010). Earlier reports have also indicated the presence of natural gas and substantially rich petroleum reserves in BDP sediments (Alam, 1989; Ganguly, 1997; Milici et al., 2002). In addition, there are several studies where presence of thermally mature petroleum derived hydrocarbons are suggested as one of the key sources of in situ derived OM in the As contaminated Holocene grey sand aquifers in BDP (Rowland et al., 2006, 2007; Héry et al., 2010). Likewise, a similar situation is suggested for the deltaic sediments in Cambodia, Taiwan and Vietnam (Lawati et al., 2012a,b). Although, microbial degradation of petroleum derived hydrocarbons in shallow Fe(III) reducing aquifers is well established (Tuccillo et al., 1999; Chapelle et al., 2002), there are few instances where researches have investigated the complex interactions involving OM utilization by in-situ microorganisms, and high As levels in aquifers (Ghosh et al., 2014; Ghosh et al. in review). Organic matter in shallow Pleistocene aquifer from an As affected region in Vietnam has been characterized recently (Lawati et al., 2012a). OM characteristics in this aquifer however does not differ significantly with respect to the young Holocene aquifers in this region (Lawati et al., 2012a), which are more prone to elevated As levels. In light of the fact that Pleistocene aquifers are considered "As-safe" (Ravenscroft et al., 2001), it is important to investigate the biogeochemical characteristics in sediments, which impact As cycling. Therefore, the main objectives of this study are to:1) characterize OM sources in the Pleistocene BSA sediments, and 2) establish the possible relationship between sedimentological characteristics vs. the distribution of trace metals and sedimentary OM distribution influencing As cycling. To the best of our knowledge this is the only study of OM characteristics in a Pleistocene BDP aquifer, and the data provides an opportunity to assess complex biogeochemical interactions in the sub-surface associated with As cycling and its mobility. 


\section{Geological settings}

90 The shallow sedimentary aquifers in BDP have been divided into late Pleistocene and Holocene alluvial deposits dating back to ca. 18 ka BP (Acharyya et al., 2000). Collision of the Indian and Eurasian plates during Miocene formed the Himalayas ca. 50 Ma. Rapid physical and chemical weathering of the Himalayas and deposition of weathered sediments resulted in formation of the Bengal fan, which prograded as a clastic wedge in the Bengal Basin (Alam, 1989; Uddin and Lundberg, 1999). Further lowering of sea-level and erosion (Lindsay et al., 1991), and rapid deposition by rivers resulted in formation of the BDP alluvial deposits (Acharyya et al., 2000). The sedimentary Holocene deposits consist of grey micaceous sand with OM rich peat lenses. In contrast, iron-rich Pleistocene deposits have coarse to fine brown sand with intermediate clay and peat layers (Alam, 1989; Acharyya et al., 2000).

100

101

102

103

104

105

106

107

108

109

110

111

112

113

Nadia district in West Bengal, India has been widely tagged as an As "hot-spot" (Bhattacharya et al., 2002; Mukherjee et al., 2008; Biswas et al., 2012 (a)). Arsenic-rich groundwater in these aquifers exceeds beyond the $10 \mu \mathrm{g} / \mathrm{l}$ 'safe' drinking water limit proposed by the World Health Organization (WHO, 2011). The study area is located in Haringhata block (N 2256.401', E 088 32.389') in the south eastern corner of Nadia district (Fig. 1). The aquifer is primarily recharged by rainfall during monsoon season. The annual rainfall in this district is $\sim 1413 \mathrm{~mm}$ and the annual temperatures are $42{ }^{\circ} \mathrm{C}$ in summer and $9{ }^{\circ} \mathrm{C}$ in winter (Statistical Handbook, 2010). Recent investigations led by us indicate that arsenite oxidizing bacterial groups are absent in this well. However, these bacterial groups were detected in grey sand aquifers (GSA) in this region (Ghosh et al., 2014). The sediment profile in this aquifer contains fine to medium brown colored sand with clay lenses occurring in-between the layers. The top layer consists predominantly of clay; in addition, there is a thick clay lens at depth of 132-156 m. Arsenic concentration in the aquifer in 2011 was $22 \mu \mathrm{g} / \mathrm{l}$.

\section{Materials and Methods}

\subsection{Sediment collection}

About 156 m of core segments were recovered by drilling a borehole using the conventional

118 household technique, involving hand percussion and reversed circulation. This method allows continuous recovery of drilled sediments. Sediment samples from surface to every $6 \mathrm{~m}$ were 
120

121

122

123

124

125

126

127

128

129

130

131

132

133

134

135

136

137

138

139

140

141

142

143

144

145

146

147

148

149

150

collected and labeled as samples 1 to 26. The samples were stored in individual separate zip lock polyethylene bags, and kept at $4{ }^{\circ} \mathrm{C}$. All the samples were freeze-dried before further geochemical analysis.

\subsection{Total organic carbon (TOC) analysis}

To remove the carbonates, the samples were pre-treated with $\mathrm{HCl}$ (Brodie et al., 2011). The percent abundance of TOC in pre-treated sediment samples were determined by an infrared detector in a TOC analyzer (Elementar Analysensysteme $\mathrm{GmbH}$ ) after combusting the samples at $1000^{\circ} \mathrm{C}$. The instrument was calibrated using the Canadian Stream Sediment (STSD-4 B-571).

\subsection{Sediment grain size analysis}

The sediments were wet sieved through a $250 \mu \mathrm{m}$ and $63 \mu \mathrm{m}$ sieve with $0.5 \mathrm{~g} / \mathrm{l}$ of $\mathrm{Na}_{3} \mathrm{PO}_{4}$ solution. The suspension volume of this fine fraction was made upto $80 \mathrm{ml}$ with the $\mathrm{Na}_{3} \mathrm{PO}_{4}$ solution and sonicated in a Vibracell CV334 (Sonics and Materials Inc.). The grain size distribution and \% sand, silt, and clay in the sediment suspension was determined with a Sedigraph III coupled with an auto-sampler Mastertech 52 (Micromeritics).

\subsection{Trace metal analysis}

The BCR protocol of the Standards, Measurement and Testing Program (formerly the Community Bureau of Reference) of the European Commission (Quevallier et al., 1997; Rauret et al., 2000) was followed for sequential extraction of metals. The protocol involved three stepby-step extractions to separate the different mineral fractions (Table 1), and is further detailed in the original references (Quevallier et al., 1997; Rauret et al., 2000). The original BCR method requires $1 \mathrm{~g}$ of sample for extraction, however Routh and Hjelmquist (2011) have shown that half of the amount can also be used. Hence, we have used $0.5 \mathrm{~g}$ of freeze-dried sediment sample in this study. Each extraction step was followed by centrifugation at $3000 \mathrm{~g}$ for $20 \mathrm{~min}$, and the supernatant was collected. After each step, a wash with $10 \mathrm{ml}$ of deionized distilled water was done. The certified standard reference sediment CRM-601 was used for extraction to check the extraction efficiency. All the four fractions (named as fraction 1 to 3) were analyzed on a Perkin Elmer NexION 300D ICP-MS. The detection limits for the different trace metals detected in each step is detailed in the supplementary data table S1. 
152 Total digestion of the sediments was carried out in accordance with the Swedish Standard 153 Method (SIS, 1993) using same amount of sample (0.5 g) as in the BCR sequential extraction 154 method. All the digestions were carried out by autoclaving the samples with $10 \mathrm{ml} 7 \mathrm{M} \mathrm{HNO}_{3}$ at $155100 \mathrm{kPa}$ and $121^{\circ} \mathrm{C}$ for $30 \mathrm{~min}$. The digested solution was cooled down and centrifuged at $15614,000 \mathrm{~g}$ for $15 \mathrm{~min}$. The extracts were named as fraction 4. The reference standard CRM-601 157 was digested in the same way as the samples.

158

159

160

161

162

163

164

165

166

167

168

169

170

171

172

173

174

175

176

177

178

179

180

\subsection{Extraction of lipid fractions}

About 10 g of freeze-dried sample was used for extraction on a Dionex 300 automated solvent extractor (programmed for a 60 min extraction cycle at 1500 psi at $100{ }^{\circ} \mathrm{C}$ and another 60 min extraction cycle at $1500 \mathrm{psi}$ at $\left.140{ }^{\circ} \mathrm{C}\right)$ with a mixture of dichloromethane and methanol $(9: 1 \mathrm{v} / \mathrm{v}$ ratio) and recovery standard consisting of $50 \mathrm{mg} / \mathrm{l}$ deuterated hexatriacontane- $\mathrm{d}_{50}$ ). Total volume of the lipid extract was reduced in a Büchi Syncore system. These total lipid extracts (TLE) were further separated into two different fractions using packed cartridges. The neutral and acid fractions were separated in $6 \mathrm{ml}$ glass columns packed with $500 \mathrm{mg}$ of Supelco Superclean LCNH-2 (Kim and Salem, 1990); the sample was eluted with $\mathrm{CH}_{2} \mathrm{Cl}_{2} /$ isopropanol (2:1, v/v; $15 \mathrm{ml}$; 'neutral fraction') and 2\% acetic acid in diethyl ether (15 ml; 'acid fraction'), respectively. The acid fraction was dissolved in $1 \mathrm{ml}$ of bromo triflouride $\left(\mathrm{BF}_{3}\right)$ in methanol and heated $\left(70{ }^{\circ} \mathrm{C}\right.$ for $120 \mathrm{~min}$ ) to convert into their corresponding methyl esters. The derivatized products were further extracted with $\mathrm{NaCl}$ and hexane. The neutral fractions were separated into polar and non-polar fractions using Bond-Elut column cartridges (Agilent Bond Elut ${ }^{\circledR}$ AL-N 500 mg, 3 ml) with hexane (5 ml; non-polar fraction) and $\mathrm{CH}_{2} \mathrm{Cl}_{2} / \mathrm{MeOH}(1: 1 \mathrm{v} / \mathrm{v}, 5 \mathrm{ml}$; polar fraction). The nonpolar fractions were dried under a gentle flow of moisture and hydrocarbon free $\mathrm{N}_{2}$ gas. The polar fractions were derivatized to their trimethylsilyl ethers using $100 \mu \mathrm{l}$ bis (trimethylsilyl) trifluroacetamide (BSTFA) and $100 \mu \mathrm{l}$ of pyridine, and heated ( $70^{\circ} \mathrm{C}$ for $120 \mathrm{~min}$ ). To ensure no contamination was introduced during the extraction and separation procedure, blanks were prepared following the same protocol. All the lipid fractions were analyzed by gas chromatography-mass spectrometry (GC-MS) after adding specific internal standards. To 
181 quantify the non-polar and polar fractions, androstane and deuterated tetracosane were used as

182 internal standards, and for the acid fractions deuterated eicosinoic acid methyl ester was used.

183

184

185

186

187

188

189

190

191

192

193

194

195

196

197

198

199

200

201

202

203

204

205

206

207

208

209

210

211

\subsection{Gas chromatography-mass spectrometry (GC-MS)}

The lipid fractions were analyzed in an Agilent $6890 \mathrm{~N}$ gas chromatograph interfaced to an Agilent 5973 MSD mass spectrometer at $70 \mathrm{eV}$ and scanning from m/z 40-600 at 2.62 scans/s. The non-polar and acid fractions were dissolved in hexane, and the polar fractions were dissolved in $\mathrm{CH}_{2} \mathrm{Cl}_{2}: \mathrm{MeOH}$ (2:1) before injection. The samples were injected in split-less mode ( $1 \mu \mathrm{l}$; inlet pressure of 10 psi with a flow rate $54.3 \mathrm{ml} / \mathrm{min}$ ) and separated on a HP-5 MS capillary column (5\% di phenyldimethyl polysiloxane; length $30 \mathrm{~m}, 250 \mu \mathrm{m}$, film thickness 0.25 $\mu \mathrm{m})$. A constant flow $(1.3 \mathrm{ml} / \mathrm{min})$ of He was used as carrier gas. The interface was set at 300 ${ }^{\circ} \mathrm{C}$, whereas the mass source was set at $230{ }^{\circ} \mathrm{C}$ and the MS quadrupole was maintained at 150 ${ }^{\circ} \mathrm{C}$, respectively. The samples were injected at $35^{\circ} \mathrm{C}$ and the oven was programmed to $130{ }^{\circ} \mathrm{C}$ at $20{ }^{\circ} \mathrm{C} / \mathrm{min}$ and then at $6{ }^{\circ} \mathrm{C} / \mathrm{min}$ to $320^{\circ} \mathrm{C}$ where it was maintained isothermally for $15 \mathrm{~min}$. Based on the retention time and mass spectra of different lipids, the compounds were identified by comparing our results with published literature (Philip, 1985; Peters et al., 2005) and online libraries (NIST library and Lipid library, 2011). The fractions were quantified with respect to the response of their internal standards.

\subsection{Statistical analyses}

To determine the correlation between As and other trace elements, a bivariate correlation test was done. Arsenic concentration in each fraction was correlated with the concentration of each element studied in that fraction, and a correlation matrix was plotted. A principal component analysis was carried out using the total concentration of different organic fraction ( $n$-alkane, $n$ alkanoic acid and $n$-alkanol), and the inorganic elemental concentrations (in total digested fraction) with respect to sediment grain size. Furthermore to predict the prime variables, which have the highest influence on the studied niche, ten organic and inorganic variables were selected to make a predictor plot. All these analyses were done using IBM $^{\circledR}$ SPSS $^{\circledR}$ Version 22.

\section{Results}

\subsection{Sediment grain size and organic carbon content}


212 The sediments ranged from grayish brown to reddish brown and deep brown in color. The

213 sediments predominantly consisted of brown sand; the top three samples were clayey. Samples at

214 a depth of 66-72 m consisted of a clay layer. Another clay layer occurred at $132 \mathrm{~m}$ and persisted

215 upto the bottom $(156 \mathrm{~m})$ of the well; this unit also contained plant fragments which could be

216 identified visibly (Fig. 2). The clay rich samples had slightly higher TOC content (0.2 to $0.67 \%)$

217 than sand (0.13 to $0.17 \%$; Fig. 2).

218

\subsection{Distribution of trace metals}

220

The reliability of BCR method for sequential extraction of metals was verified using the CRM601 standard along with the sediment samples. After $84 \mathrm{~m}$, alternate samples were selected for

222 sequential extraction. In CRM-601, 6 trace elements were assessed in each extraction step and also for the pseudo-total elemental concentration (López-Sánchez et al., 1998). Since $7 \mathrm{M} \mathrm{HNO}_{3}$ was used to extract pseudo total elemental concentration, it is not strictly comparable to the reported values in CRM-601.

Trace element concentrations of different extraction steps for CRM-601 standard were compared to their 95\% confidence interval (López-Sánchez et al., 1998; Table 2). The concentrations for $\mathrm{Cu}, \mathrm{Ni}$ and $\mathrm{Zn}$ in fraction 1 of this study were not within the confidence limit. In fractions 2, concentrations of $\mathrm{Cr}, \mathrm{Cu}, \mathrm{Ni}$ and $\mathrm{Zn}$ were not within the confidence limit, and in fraction 3 trace metal concentrations of $\mathrm{Ni}, \mathrm{Pb}$ and $\mathrm{Zn}$ were not within the confidence limit. $\mathrm{Zn}$ was not measured within confidence in any of the extraction steps. From these results, it was concluded that all steps in the BCR extraction scheme in this study were only partially reliable, and was similar to our experience of using this protocol for sequential extraction in another study on BDP 235 sediments (Routh and Hjelmquist, 2011).

Samples from top layers and the clay lenses had the highest concentrations for most elements. 238 The total As concentration in these sediments varied between 1.73 and $21.2 \mathrm{mg} / \mathrm{kg}$ (Fig. 3). The highest As concentration occurred in samples 1, 2, 7, 8 and 24. Arsenic was mainly associated with the residual fraction. However, in other readily available forms (e.g., As complexes with organic matter and Fe-Mn oxy-hydroxides) extracted in fractions 1-3 ranged between 0.01 to 
242

243

244

245

246

247

248

249

250

251

252

253

254

255

256

257

258

259

260

261

262

263

264

265

266

267

268

269

270

$20.0 \mathrm{mg} / \mathrm{kg}$. Arsenic associated with the reducible fraction 2 occurred in samples 1, 2, 7, 8, 9, 24 and 26, and ranged from 0.23 to $4.65 \mathrm{mg} / \mathrm{kg}$ (Fig. 3).

The total Fe concentration in sediments varied between 854 and 10,661 mg/kg (Fig. 3); the highest concentration occurred in fraction 4 followed by fractions 3 and 2. The total Mn content varied between 12.6 and $253 \mathrm{mg} / \mathrm{kg}$. Mn primarily occurred in fractions 2 and 3 (Fig. 3). The total P concentration in sediments varied between 252 to $2530 \mathrm{mg} / \mathrm{kg}$ (Fig. 3). Phosphorus mainly occurred in fractions 2 and 4.

\subsection{Distribution of sedimentary lipid biomarkers}

n-Alkanes

The total $n$-alkane concentration in sediment samples varied significantly between the different depth intervals (Supplementary data, Table S1), and ranged from 0.05 to $25.0 \mathrm{ng} / \mathrm{mg}$. The $n$ alkane concentrations did not show a steady decline with depth for the first $54 \mathrm{~m}$, however after this depth interval, decline in $n$-alkane concentration was more rapid. The clay lens present at depth 138-154 m with visible trace of plant material showed high $n$-alkane concentration (Supplementary data, Table S1). Unimodal distribution of $n$-alkanes was observed with the predominance of high molecular weight (HMW) $n$-alkanes ( $\left.>n-\mathrm{C}_{20}\right)$ in samples with high (27 to $70 \%)$ silt and clay content $(1,2,3,11,24,25)$. A predominance of HMW odd $n$-alkanes $n$ - $C_{27}$, $n$ - $\mathrm{C}_{29}, n-\mathrm{C}_{31}$ was observed in all these samples, except in sample 25 (144-150 m), where equal predominance of odd and even HMW $n$-alkanes was observed (Fig. 4). Overall the total HMW $n$-alkanes concentration ranged between 0.006 to $0.55 \mathrm{ng} / \mathrm{mg}$, and the total low molecular weight (LMW) $n$-alkane concentration ranged between 0.03 to $2.49 \mathrm{ng} / \mathrm{mg}$. The distribution of these biomarkers was used to assess the source(s) of these compounds based on diagnostic ratios as discussed below.

1) Carbon preference index (CPI) including $n-\mathrm{C}_{23}$ to $n$ - $\mathrm{C}_{32} n$-alkanes (Allan and Douglas, 1977) was modified based on the abundance and distribution of different alkane monomers in our samples. We separated them as $\mathrm{CPI}_{\mathrm{TOT}}\left(n-\mathrm{C}_{13}\right.$ to $n-\mathrm{C}_{35}$ ), $\mathrm{CPI}_{\mathrm{Lmw}}\left(n-\mathrm{C}_{13}\right.$ ton- $\mathrm{C}_{21}$ ) and $\mathrm{CPI}_{\mathrm{Hmw}}$ $\left(n-\mathrm{C}_{23}\right.$ to $\left.n-\mathrm{C}_{35}\right)$. 


$$
\mathrm{CPI}_{\mathrm{TOT}}=\frac{\Sigma\left(\mathrm{C}_{13} \text { to } \mathrm{C}_{33}\right)_{\text {odd }}+\Sigma\left(\mathrm{C}_{15} \text { to } \mathrm{C}_{35}\right)_{\text {odd }}}{2 \Sigma\left(\mathrm{C}_{14} \text { to } \mathrm{C}_{34}\right)_{\text {even }}}
$$

271

$$
\mathrm{CPI}_{\mathrm{LMW}}=\frac{\Sigma\left(\mathrm{C}_{13} \text { to } \mathrm{C}_{19}\right)_{\text {odd }}+\Sigma\left(\mathrm{C}_{15} \text { to } \mathrm{C}_{21}\right)_{\text {odd }}}{2 \Sigma\left(\mathrm{C}_{14} \text { to } \mathrm{C}_{20}\right)_{\text {even }}}
$$

272

$$
\mathrm{CPI}_{\mathrm{HMw}}=\frac{\Sigma\left(\mathrm{C}_{23} \text { to } \mathrm{C}_{33}\right)_{\text {odd }}+\Sigma\left(\mathrm{C}_{25} \text { to } \mathrm{C}_{35}\right)_{\text {odd }}}{2 \Sigma\left(\mathrm{C}_{24} \text { to } \mathrm{C}_{34}\right)_{\text {even }}}
$$

273

274 The $\mathrm{CPI}_{\text {тот }}$ ranged from 0.22 to 6.03, whereas the $\mathrm{CPI}_{\mathrm{LMw}}$ ranged between 0.12 to 1.41 and $275 \mathrm{CPI}_{\mathrm{HMw}}$ ranged from 0.38 to 25.6 (Fig. 4).

276

277 2) Terrigenous/aquatic ratio (TAR) was proposed by Bourbonniere and Meyers (1996) to 278 estimate the terrigenous or aquatic derived OM input to sediments. TAR was modified to 279 accommodate the distribution of $n$-alkanes, and the value ranged from 0.60 to 42.7, however the 280 TAR value in sample 25 was extremely high (Fig. 4).

281

TAR $=\frac{\Sigma\left(\mathrm{C}_{27} \text { to } \mathrm{C}_{31}\right)_{\text {odd }}}{\Sigma\left(\mathrm{C}_{15} \text { to } \mathrm{C}_{19}\right)_{\text {odd }}}$

282 3) Average Chain Length (ACL) proposed by Cranwell et al. (1987) to describe the type of 283 vegetation ranged from 29 to 31 (Fig. 4) in this study.

$$
\begin{gathered}
\mathrm{ACL}=\frac{\Sigma\left(\mathrm{nC}_{\mathrm{n}} \text { to } \mathrm{mC}_{\mathrm{m}}\right)_{\text {odd }}}{\Sigma\left(\mathrm{C}_{\mathrm{n}} \text { to } \mathrm{C}_{\mathrm{m}}\right)_{\text {odd }}} \\
\text { where } \mathrm{n}=25 \text { and } \mathrm{m}=33
\end{gathered}
$$

\section{n-Alkanoic acids}

287 The average total $n$-alkanoic acid concentration is greater than $99 \%$ of the total lipid extract ( $\sum n$ 288 alkane $+\sum n$-alkanoic acid $+\sum n$-alkanol $+\sum$ sterol). The total $n$-alkanoic acid concentration 289 ranged from 307 to $6031 \mathrm{ng} / \mathrm{mg}$ in sediments (Supplementary data Table S2). The sediment 290 samples from 0 to $36 \mathrm{~m}$ had higher concentration of total $n$-alkanoic acids, which decreased 291 steeply until $138 \mathrm{~m}$ (Fig. 4). The LMW $n$-alkanoic acids $n$-C $\mathrm{C}_{16: 0}$ and $n$-C $18: 0$ were most abundant 292 followed by HMW $n$-alkanoic acids ( $n-\mathrm{C}_{24: 0}, n-\mathrm{C}_{26: 0}, n-\mathrm{C}_{28: 0}$ and $\left.n-\mathrm{C}_{30: 0}\right)$. Among odd $n$ - 
293 alkanoic acids, there was dominance of $n-\mathrm{C}_{25: 0}$ followed by $n-\mathrm{C}_{23: 0}$ and $n-\mathrm{C}_{17: 0}$ monomers. Many 294 unsaturated $n$-alkanoic acids were detected amongst which unsaturated $\mathrm{C}_{18}$ alkanoic acids

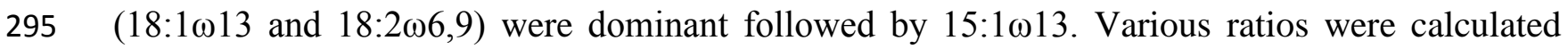
296 based on the distribution of different $n$-alkanoic acids.

1) The Carbon Preference Index (CPI of fatty acids) was modified by (Matsuda and Koyama, 299 1977) by dividing it into low molecular weight $\mathrm{CPI}_{\mathrm{L}}\left(\mathrm{C}_{12}\right.$ to $\left.\mathrm{C}_{18}\right)$ and high molecular weight $\mathrm{CPI}_{\mathrm{H}}\left(\mathrm{C}_{22}\right.$ to $\left.\mathrm{C}_{32}\right)$ for determining the source of $n$-alkanoic acids.

$\mathrm{CPI}_{\mathrm{L}}=\frac{\Sigma\left(\mathrm{C}_{12} \text { to } \mathrm{C}_{16}\right)_{\text {even }}+\Sigma\left(\mathrm{C}_{14} \text { to } \mathrm{C}_{18}\right)_{\text {even }}}{2 \Sigma\left(\mathrm{C}_{13} \text { to } \mathrm{C}_{17}\right)_{\text {odd }}}$

301

302

303

The $\mathrm{CPI}_{\mathrm{L}}$ was high (ranged from 5.34 to 40.3 ) compared to $\mathrm{CPI}_{\mathrm{H}}$ which ranged from 1.39 to 4.31 (Fig. 4).

2) The terrigenous:aquatic fatty acid ratio (TAR ${ }_{\mathrm{FA}}$; proposed by Meyers (1997) was used to predict the source of fatty acids in sediments.

$\operatorname{TAR}_{\mathrm{FA}}=\frac{\sum\left(\mathrm{C}_{24} \text { to } \mathrm{C}_{28}\right)_{\text {even }}}{\Sigma\left(\mathrm{C}_{12} \text { to } \mathrm{C}_{16}\right)_{\mathrm{even}}}$

The $\mathrm{TAR}_{\mathrm{FA}}$ value ranged from 0.03 to 0.89 ; sample number 26 had the highest $\mathrm{TAR}_{\mathrm{FA}}$ value 309 (Fig. 4).

\section{n-Alkanol}

312 The $n$-alkanol concentration within the sediment profile varied from 0.02 to $7.17 \mathrm{ng} / \mathrm{mg}, n-\mathrm{C}_{22}$ 313 alkanol was the most predominant monomer. In order to assess the preferential preservation of 314 different organic compounds, the higher plant alkane index (HPA; Westerhausen et al., 1993) 315 was used.

$$
\mathrm{HPA}=\frac{\left(\mathrm{C}_{24}+\mathrm{C}_{26}+\mathrm{C}_{28}\right)_{\mathrm{alkanol}}}{\left(\mathrm{C}_{25}+\mathrm{C}_{27}+\mathrm{C}_{29}\right)_{\text {alkane }}+\left(\mathrm{C}_{24}+\mathrm{C}_{26}+\mathrm{C}_{28}\right)_{\mathrm{alkanol}}}
$$

317 The HPA values ranged from 0.02 to 0.96 (Fig. 4). 
Other than these compounds, sterols and stanols were also detected in a few samples. The top 0-6 core contains coprostane. The thick clay-rich layer at the bottom of the core (132 to $156 \mathrm{~m}$ ) contained higher stanols and sterols including: brassicasterol, $5 \alpha$-brassicastanol, $5 \alpha$-stigmastanol and situstanol.

\section{Discussion}

\subsection{Inorganic characteristics}

Riverine deposits with sand fining upward into silt with clay bands is typical of BDP sediments (Tucker et al., 1991; Umitsu, 1993). These stacked packages of sediments were probably deposited in channels and the fining-upward sequences have formed during channel migration (Umitsu, 1993; Goodbred and Kuehl, 2000; McArthur et al., 2004). Because of the inherent dynamism associated with these depositional environments there is strong variability/ heterogeneity in sediment characteristics observed in BDP. The predominantly brown colored iron stained sediment with low TOC content in the study area has previously been described as early to mid-Pleistocene deposits in age (Umitsu, 1993; Alam, 1989). The aquifer has orange to brown colored clayey sediments on top, with brown colored sands in deeper layers. The brown color is due to the high iron content in these sediments, and suggests oxidation of bound Fe(hydr)oxides minerals (Biswas et al., 2012b).

The total As content (1.73 and $21.2 \mathrm{mg} / \mathrm{kg}$ ) in these samples is above the world average value reported by Smedley and Kinniburgh (2002) for unconsolidated sediments. A bivariate correlation of As with other metals in each fraction from all the sediment samples (Table 3), indicate significant correlation of As with Fe in all fractions [fraction $1(\mathrm{r}=0.59 ; \mathrm{p}=0.007)$, fraction $3(\mathrm{r}=0.76 ; \mathrm{p}=0.00)$ and fraction $4(\mathrm{r}=0.79 ; \mathrm{p}=0.00)]$.

In fraction 1 which contains carbonates, the samples have high concentrations of $\mathrm{Ca}$, $\mathrm{Mn}$ and $\mathrm{Na}$. The high Ca content in this fraction occurs in most samples (945 to 30,652 mg/kg; Fig. 3), and shows a strong correlation with $\mathrm{Mn}(\mathrm{r}=0.97 ; \mathrm{p}=0.00)$ indicating the abundance of carbonate minerals in BSA sediments. This is consistent with the high inorganic carbon content in groundwater (104 mg/l) and low DOC level (7.8 mg/l; Ghosh et al., in review). Fraction 1 also contains relatively higher Mn concentration than Fe and As (Fig. 3), suggesting incorporation of 
Mn into carbonate minerals like rhodochrosite $\left(\mathrm{MnCO}_{3}\right)$ and $\mathrm{CaCO}_{3}-\mathrm{MnCO}_{3}$ (Stollenwerk et al., 2007; von Brömssen et al., 2008).

Fraction 2 containing (hydr)oxides have high concentration of many elements ( $\mathrm{Cd}, \mathrm{Fe}, \mathrm{Pb}, \mathrm{V}$ and $\mathrm{Zn}$ ). Iron is more abundant in fraction 2 compared to its presence in the other fractions (678 to $6286 \mathrm{mg} / \mathrm{kg}$ ); this is in agreement with other studies on BDP sediments from this region (Routh and Hjelmquist, 2011; Biswas et al., 2012b). However, there is absence of significant correlation of Fe with As in fraction 2 (Table 3), which is perhaps due to variation in redox potential along vertical or horizontal zones in BDP aquifers (Nickson et al., 2000; BGS and DPHE, 2001; McArthur et al., 2004).

Fraction 3 containing elements bound to sulfides and OM has high concentration of $\mathrm{Mg}$ and $\mathrm{Mn}$. Arsenic has significant correlation with sulfidic metals (e.g., $\mathrm{Ni}, \mathrm{Cu}, \mathrm{Pb}, \mathrm{Cd}$ and $\mathrm{Cr}$ ) in fraction 3 (Table 3). Although the concentration of $\mathrm{Fe}$ in this fraction is lower (72 to $2058 \mathrm{mg} / \mathrm{kg}$ ) compared to fraction 2, but significant correlation between As and Fe occurs in this fraction $(\mathrm{r}=$ 0.76; $p=0.00$ ) thereby suggesting presence of As bearing sulfidic minerals such as pyrite. However, this needs to be confirmed with x-ray diffraction analysis. This trend provides evidence supporting the earlier studies, where presence of sulfidic minerals of Fe like pyrite was detected along with Fe (hydr)oxides such as ferric hydroxide $\left[\mathrm{Fe}(\mathrm{OH})_{3}\right]$, goethite $(\mathrm{FeOOH})$, hematite $\left(\mathrm{Fe}_{2} \mathrm{O}_{3}\right)$, and magnetite $\left(\mathrm{Fe}_{3} \mathrm{O}_{4}\right)$ (Das et al., 1996; Chakraborti et al., 2001; Biswas et al., 2012b). The overall low concentration of all elements in this fraction is also in agreement with the low TOC content in BSA sediments.

Fraction 4 containing metals bound to crystalline and silicate forms have high As, Fe and Mn concentrations. There is a significant correlation of As with many transition metals in fraction 4 (e.g., Ni, Cu, Zn, Pd, Cd, Mo, Cr and V; Table 3). This suggests strong association of most of these elements within the crystalline silicate lattice, which protects them from chemical/physical weathering processes (Hjorth, 2004; Routh and Hjelmquist, 2011).

Overall, there is an absence of significant correlation between As and $\mathrm{Mn}$ in all fractions, except fraction 4. Likewise, Mn occurs in low concentration in Haringhata groundwater (Ghosh et al., in 
review), which contrasts with other studies in BSAs (Biswas et al., 2012b). The results indicate that BSAs are mainly a Fe dominated system (see supplementary data Fig. S1). Moreover, the trend suggests that complexation of As with Fe-bound minerals is preferred over Mn-bound minerals. This contrasts findings of other studies (Nickson et al., 2000; BGS and DPHE, 2001; McArthur et al., 2004; Routh and Hjelmquist, 2011). However, these studies were essentially conducted in the grey sand aquifers (GSA) in BDP.

\subsection{Organic matter sources and their distribution}

The overall low TOC content in these sediments (even in the clay-rich intervals) is typical of alluvial settings and has been reported from other sites in BDP aquifers (McArthur et al., 2004; Rowland et al., 2006; Routh and Hjelmquist, 2011). Alluvial sediments in general consist of degraded and reworked OM, and only the peat-rich intervals in BDP sediments have high TOC content (McArthur et al., 2004; Rowland et al., 2006). Moreover, BDP sediments have been subjected to microbial degradation of OM, which results in low TOC and C/N ratio as a result of early diagenetic changes (Routh and Hjelmquist, 2005). Previous studies suggest that OM degradation during microbial respiration in the BDP sediments drives these aquifers to anoxia, and impacts the release of As in groundwater (McArthur et al., 2004; Islam et al., 2004; Routh and Hjelmquist, 2005). Thus OM characteristics and its inherent quality play an important role in driving microbial processes associated with As cycling. While OM quality particularly its reactivity is an important aspect, nevertheless it is the presence of specific enzymes in the bacterial community, which determine if the OM can be used as a substrate for metabolic processes in the sub-surface.

The distribution and suite of different biomarkers identified in the BSA sediments is similar to those in groundwater analyzed from this aquifer (Ghosh et al., in review). Sediment and water samples from this well indicate unimodal distribution and predominance of HMW $n$-alkanes indicating a dominant input of terrestrial OM. The total $n$-alkane concentrations (except the clay lens at $138 \mathrm{~m}$ ) are similar to the total $n$-alkane concentrations reported by Rowland et al. (2006) in GSAs. The steady decline in total $n$-alkane concentrations with depth as reported by Rowland et al. (2006) is however absent in this sediment core. The total LMW $n$-alkane concentration is high in the clay and silt rich layer, but is notably much lower than the HMW n-alkane 
412 concentrations. This trend suggests low abundance of microbial derived inputs produced from 413 degradation of sedimentary OM. The odd over even predominance of $n$-alkane monomers 414 calculated using $\mathrm{CPI}_{\mathrm{TOT}}$ shows there is higher input of plant derived $\mathrm{OM}$ in the clay and silt rich 415 layers in the core. In particular, the bottom layers which indicate presence of plant fragments 416 shows high $\mathrm{CPI}_{\mathrm{HMw}}$ values confirming the presence of un-degraded and immature sedimentary 417 OM in this interval (Peters et al., 2006). However within this clay interval (138-156 m), sample 418 collected at depth of 144 to $150 \mathrm{~m}$, which indicates plant fragments does not show an odd over 419 even predominance of $n$-alkane distribution. Although the sample is lean in LMW $n$-alkanes and 420 is instead enriched in HMW n-alkanes $\left(n-C_{23}\right.$ to $\left.n-C_{35}\right)$, this sample interval lacks the dominance 421 of odd over even monomers (Fig. 4). Such a distribution pattern of hydrocarbons in sediments 422 suggests presence of OM derived from anthropogenic sources like bitumen and oils and/ OM 423 derived from carbonate and/ rock evaporites (Peters et al., 2005; Burgman and Ali, 2009). The 424 high dissolved inorganic carbon content in groundwater (104 mg/l; Ghosh et al., in review), 425 abundance of $\mathrm{Ca}$ in the carbonate fraction in this sample (fraction 1; Fig. 3) and high loss-of426 ignition value at $950{ }^{\circ} \mathrm{C}$ (D. Ghosh, unpublished study), supports the presence of carbonates in 427 deeper layers.

TAR value corresponds well with the Sedigraph profile, and indicates increased input of higher 430 plant matter in samples rich in clay and silt content. TAR increases rapidly in the bottom clay interval and further confirms the high terrigenous input in this sample. The ACL value ranges

432 from 29 to 31 and confirms the overall predominance of terrestrial OM (Cranwell et al., 1987; Duan and He, 2011) in BSA sediments.

The high abundance of monounsaturated $n$-alkanoic acids $\mathrm{C}_{16}$ and $\mathrm{C}_{18}$ is unspecific because it 436 can be derived from multiple sources e.g., marine/terrigenous bacteria, animals or plants. 437 However, high abundance of long chain $n$-alkanoic acid $\left(\mathrm{C}_{24}\right.$ to $\left.\mathrm{C}_{30}\right)$ is suggested to indicate 438 epicuticular leaf waxes of vascular plants (Bianchi and Canuel, 2011). The predominance of $\mathrm{C}_{18}$ 439 derived unsaturated alkanoic acids suggest algae as well as higher plant inputs into these sediments. Notably, the even-over-odd predominance among LMW $n$-alkanoic acids indicate 441 microbial reworking in the sediments (Zou et al., 2004; Bianchi and Canuel, 2011 and references 
442 therein). The higher plant derived input in the deepest samples is also supported by their high 443 TAR $_{F A}$ values.

Amongst the $n$-alkanols, abundance of $\mathrm{C}_{22}-\mathrm{OH}$ indicates presence of suberin derived from plant wax (Bull et al., 2000), or other sources such as eustigmatophytes (Volkman et al., 1999), phototrophic marine and fresh water microalgae (Jaffé et al., 2001). However, in these samples alcohols are mostly likely derived from suberin because significant input from other sources in sub-surface sediments is unlikely. Also, the HPA index is found to be $>1$ in the clay rich samples indicating preferential preservation of $n$-alkanes over $n$-alkanols. Bacterial reworking of more functionalized organic compound as alcohols is more likely than saturated $n$-alkanes (Routh et al., 2013). Along with $n$-alkanols, few sterol and stanol monomers have been detected in some samples associated with the polar fractions. For example, presence of coprostane in the top layer signifies anthropogenic inputs from sewage (Brown and Wade, 1984). The trend suggests that contamination from such anthropogenic inputs into the sub-surface is restricted to surficial layers and there is perhaps less mixing. The HMW sterols and stanols like brassicasterol, $5 \alpha-$ brassicastanol, 5 $\alpha$-stigmastanol and situstanol are diagnostic markers for plant derived OM sources (Volkman, 1986). Stanols are preferentially preserved over sterols (Routh et al., 2013), and presence of these functional compounds in clay rich sediments implies that despite better preservation, degradation of functional components still occurs in these sediment intervals.

High plant derived OM inputs occur in the clay rich intervals, where low $\mathrm{CPI}_{\mathrm{HMw}}$ value indicates no apparent predominance of odd over even HMW $n$-alkanes and preferential preservation of $n$ alkanes over alkanols as denoted by the HPA ratio. In fact presence of LMW $n$-alkanes and $n$ alkanoic acids, which are derived from microbial cells suggest microbial degradation of OM (Cranwell et al., 1987; Meyers and Ishiwatari, 1993; Holtvoeth et al., 2010). Based on the lipid distribution profile, it can be said that $\mathrm{OM}$ in sand appears to undergo higher biodegradation in comparison to the clay lenses above or below it. Similar distribution of biomarkers with high terrigenous input has also been observed in GSA sediments in BDP (Rowland et al., 2006). Notably, these studies have shown the presence of petroleum derived thermally 'mature' 472 participating in reductive dissolution of As in these aquifers (Rowland et al., 2006; Héry et al., 
473 2010). Interestingly, there is no indication of petroleum derived hydrocarbons in the Pleistocene 474 BSA sediments, which instead indicate predominance of complex and young immature OM that 475 has undergone limited post-diagenetic changes. Perhaps lack of some of these OM sources play a 476 crucial role in driving As concentration and cycling in the BDP aquifers since this is one of the 477 major differences we find in OM quality between the BSA and GSA sediments.

478

\subsection{Correlation between organic and inorganic components}

A principal component analysis was carried out to determine if the distribution of different lipid biomarkers correlated with elemental concentration grain size (Fig. 5). The correlation between the different components is described by the factor score, whereby higher values represent greater significance. The lowest level for significant factor score is chosen as 0.5. The three principal components (PC) represent $77.8 \%$ of variability in geochemical data (Table 4). The factor scores obtained for each component are a type of correlation coefficient, and higher values are associated with greater significance. PC1 describes $40.5 \%$ of the total variance with high loadings of metal forming As complexes within the silt and clay rich fraction, Fe and Mn. PC2 is described only by lipid biomarkers, and does not correlate with sediment type or metal complexes. The third component PC3 indicates correlation between fine sand and P content in the sample. Thus, from factor analysis it is clear that the inorganic and organic components in the aquifer sediment are naturally exclusive, and they are not interdependent.

\section{4}

A built model is created based on predictor space, where nearest neighbor analysis is done for the 20 samples used for biomarker characterization. Out of 20 samples, 15 are considered as training i.e., they describe $75 \%$ of the model, and remaining 5 samples are holdouts. A lowerdimensional projection of the predictor space (Fig. 6), contains a total of 10 different organic and inorganic predictors (As, Fe, Mn, P, and S concentrations, fine sand, silt and clay composition, $\sum n$-alkane, $\sum n$-alkanol, and $\sum n$-alkanoic acid concentration) is plotted. The plot (Fig. 6) indicates that As, Fe and fatty acid content in the sediment samples are the key predictors of the model, which are probably driving the biogeochemical reactions of the aquifer system. This gives a clear indication that both organic and inorganic components co-influence the distribution 502 and fluxes of different elements in the system. 


\section{Conclusions}

This is the first study of BSA sediments in BDP aquifers from West Bengal, where we characterize different lipid fractions in the SOM pool in addition to measuring the distribution of metals in different fractions using the BCR sequential extraction protocol. Although microbial As(III) oxidation occurs in GSA aquifers in this region, this process is absent in the BSA investigated earlier (Ghosh et al., 2014). This is perhaps due to the absence of specific reactive organic and/or inorganic compounds, which impact the As oxidizing bacterial communities in these sediments. There are very few differences found amongst the BSA and GSA aquifers in BDP. In GSAs, As forms complexes with Mn-bound minerals. In contrast, in BSAs, As is mainly related to Fe-bound minerals and the overall concentration of $\mathrm{Mn}$ is low in these sediments. Distribution of lipids in BSA sediments shows the presence and better preservation of terrigenous OM along with less microbial degradation. However, such hydro-geochemical differences can potentially influence the indigenous microbial flora. Low microbial metabolism keeps the BSAs As-safe (Dhar et al., 2011) which perhaps results from better preservation of OM due to its complex structure. Moreover the microbial communities in the sub-surface are probably different, which impedes As mobilization and cycling in BSAs. However, in terms of the microbial communities in BSA and GSA groundwaters, we did not see major differences in the bacterial communities, and they are represented by common soil bacteria (Ghosh et al., 2014). Notably earlier studies have shown that imperfect sealing between the shallow GSAs and deep BSAs may transfer the arsenite reducing bacteria in groundwater from GSAs into BSAs (Dhar et al., 2011), which may eventually affect the 'As-safe' tag for Pleistocene aquifers in BDP. Thus, key differences between potentially vulnerable 'As safe' BSA and As contaminated GSA behooves further detailed studies including in situ microbial processes to understand the long term safety viability and characteristics in these aquifers.

\section{Acknowledgements}

DG thanks the Department of Science and Technology, Government of India for providing the PhD INSPIRE fellowship. The study was financed by the Swedish Research Link-Asia Program and was done at Linköping University, Sweden. Apurba Mandal helped with drilling the well. We acknowledge Kalpana Singhamshetty for helping with TOC analysis. We are grateful to Susanne Karlsson and Lena Lundman for their assistance in the laboratory. 


\section{References}

Alam, M., 1989. Geology and depositional history of Cenozoic sediments of the Bengal basin of Bangladesh. Palaeogeography Palaeoclimatology Palaeoecology 69, 125-139.

Allan, J., Douglas, A.G., 1977. Variations in the content and distribution of $n$-alkanes in a series of Carboniferous vitrinites and sporinites of bituminous rock. Geochimica et Cosmochimica Acta 41, 1223-1230.

Acharyya, S.K., Lahiri, S., Raymahashay, B.C., Bhowmik, A., 2000. Arsenic toxicity of groundwater in parts of the Bengal basin in India and Bangladesh: the role of Quaternary stratigraphy and Holocene sea-level fluctuation. Environmental Geology 39, 1127-1137.

Anwar, H.M., Yoshioka, T., Konohira, E., Akai, J., Freitas, M.C., Tareq, S.M., 2010. Sources of organic carbon and depositional environment in the Bengal delta plain sediments during the Holocene period. Limnology 11, 133-142.

Berg, M., Tran, H.C., Nguyen, T.C., Pham, T.C., Schertenleib, R., Giger, W., 2001. Arsenic contamination of groundwater and drinking water in Vietnam: a human health threat. Environmental Science and Technology 35, 2621-2626.

Bhattacharya, P., Chatterjee, D., and Jacks, G., 1997. Occurrence of arsenic contaminated groundwater in alluvial aquifers from Delta Plains, Eastern India: Options for safe drinking water supply. International Journal of Water Resource Management 13, 79-82.

Bhattacharya, P., Jacks, G., Ahmed, K. M., Routh, J., Khan, A. A., 2002. Arsenic in groundwater of the Bengal Delta Plain aquifers in Bangladesh, Bulletin of Environmental Contamination and Toxicology 69, 538-545.

Bhattacharya, A., Routh, J., Jacks, G., Bhattacharya, P., Mörth, M., 2006. Environmental assessment of abandoned mine tailings in Adak, Västerbotten district, northern Sweden. Applied Geochemistry 21, 1760-1780.

BGS, DPHE, 2001. Arsenic contamination of ground water in Bangladesh. In: Kinniburgh, D.G., Smedley, P.L. (Eds), British Geological Survey Report WC/00/19, Final Report, vol. 2, British Geological Survey, Keyworth.

Bianchi, T.S., Canuel, E.A., 2011. Chemical Biomarkers in Aquatic Ecosystem. Princeton University Press, Oxfordshire; pp. 144-168.

Biswas, A., Nath, B., Bhattacharya, P., Halder, D., Kundu, A. K., Mandal, U., 2012a. Testing tubewell platform color as a rapid screening tool for arsenic and manganese in drinking water wells. Environmental Science and Technology 46, 434-40. 
Biswas, A., Nath, B., Bhattacharya, P., Halder, D., Kundu, A.K., Mandal, U., Mukherjee, A., Chatterjee, D., Mörth, C.M., Jacks, G., 2012b. Hydrogeochemical contrast between brown and grey sand aquifers in shallow depth of Bengal Basin: Consequences for sustainable drinking water supply. Science of Total Environment 431, 402-412.

Bourbonniere, R.A., Meyers, P.A., 1996. Sedimentary geolipid records of historical changes in the watersheds and productivities of Lakes Ontario and Erie. Limnology Oceanography 41, 352359.

Brodie, C.R., Casford, J.S.I., Lloyd, J.M., Leng, J., Heaton, T.H.E., Kendrick, C.P., Yongqiang, Z., 2011. Evidence for a bias in $\mathrm{C} / \mathrm{N}, \delta^{13} \mathrm{C}$ and $\delta^{15} \mathrm{~N}$ values of bulk organic matter, and on environmental interpretation from a lake sedimentary sequence by pre-analysis acid treatment methods. Quaternary Science Reviews 30, 3076-3087.

Brown, R.C., Wade, T.L., 1984. Sedimentary coprostanol and hydrocarbon distribution adjacent to a sewage outfall. Water Research 18, 621-632.

Bull, I.D., van Bergen, P. F., Noh, C. J., Poulton, P. R. and Evershed, R. P., 2000. Organic geochemical studies of soil from Rothamsted classical experiment-V. The fate of lipids in different long-term experiments. Organic Geochemistry 31, 389-408.

Burgan, A.M., Ali, C.A., 2009. Characterization of the black shales of the Temburong formation in West Sabah, East Malaysia. European Journal of Scientific Research 30, 79-98.

Chakraborti, D., Basu, G.K., Biswas, B.K., 2001. Characterization of arsenic bearing sediments in the Gangetic delta of West Bengal, India. In: Arsenic exposure and health effect IV. Chappell, W.R., Abernathy, C.O., Calderon, R.L. Elsevier Science, Oxford.

Chapelle, F.H., Bradley, P.M., Lovley, D.R., O’Neill, K., Landmeyer, J.E., 2002. Rapid evolution of redox processes in a petroleum hydrocarbon-contaminated aquifer. Groundwater 40, 353-360.

Cranwell, P.A., Eglinton, G., Robinson, N., 1987. Lipids of aquatic organisms as potential contributors to lacustrine sediments. Organic Geochemistry 11, 513-527.

Curray, J.R., Moore, D.G., 1974. Sedimentary and tectonic processes in the Bengal deep-sea fan geosynclines, in: Burk C.R. and Drake C.L. (Eds.), Geology of Continental Margins. Springer, New York.

Das, D., Samanta, G., Mandal, B.K. et al., 1996. Arsenic in groundwater in six district of West Bengal, India. Environmental Geochemistry and Health 18, 5-15.

Dhar, R.K., Zheng, Y., Saltikov, C.W., Radloff, K.A., Mailloux, B.J., Ahmed, K.M., van Geen, A., 2011. Microbes enhance mobility of arsenic in Pleistocene aquifer sand from Bangladesh. Environmental Science and Technology 45, 2648-2654. 
Duan, Y., He, J., 2011. Distribution and isotopic composition of $n$-alkanes from grass, reed and tree leaves along a latitudinal gradient in China. Geochemical Journal 45, 199-207.

Farooq, S., Chandrasekharan, D., Norra, S., Berner, Z., Eiche, E., Thambidurai, P., Stüben, D., 2010. Temporal variation in arsenic concentration in the groundwater of Murshidabad District, West Bengal, India. Environmental Earth Sciences 62, 1-10.

Ganguly, S., 1997.Petroleum geology and exploration history of the Bengal Basin in India and Bangladesh. Indian Journal of Geology 69, 1-25.

Ghosh, D., Bhadury, P., Routh, J., 2014. Diversity of arsenite oxidizing bacterial communities in arsenic-rich deltaic aquifers in West Bengal, India. Frontiers in Microbiology 5, 1-14.

Goodbred Jr., S.L., Kuehl, S.A., 2000. The significance of large sediment supply, active tectonism and eustasy on margin sequence development: late Quaternary stratigraphy and evolution of the Ganges-Brahmaputra delta. Sedimentary Geology 133, 227-248.

Guha Majumdar, D.N., Chakraborty, A.K., Ghosh, A., Chakraborty, D.P., Dey, S.B., Chattopadhyay, N., 1988. Chronic arsenic toxicity from drinking tube well water in rural West Bengal Bulletin. World Health Organization 66, 499-506.

Harvey, C.F., Swartz, C. H., Badruzzaman, A.B.M., Keon-Blute, N., Yu, W., Ashraf Ali, M., Jay, J., Beckie, R., Niedan, V., Brabander, D., Oates, P.M., Ashfaque, K.N., Islam, S., Hemond, H.F. and Ahmed, M.F., 2002. Arsenic mobility and groundwater extraction in Bangladesh. Science 298, 1602-1606.

Héry, M., Van Dongen, B.E., Gill, F., Mondal, D., Vaughan, D.J., Pancost, R.D., Polya, D.A., Lloyd, J.R., 2010. Arsenic release and attenuation in low organic carbon aquifer sediments from West Bengal. Geobiology 8, 166-168.

Hjorth, T., 2004. Effects of freeze-drying on partitioning patterns of major and trace elements in lake sediments. Analytical Chemistry Acta 526, 95-102.

Holtvoeth, J., Vogel, H., Wagner, B., Wolff, G.A., 2010. Lipid biomarkers in Holocene and glacial sediments from ancient lake Ohrid (Macedonia, Albania). Biogeosciences 7, 3473-3489.

Horneman, A., van Geen, A., Kent, D.V., Mathe, P.E., Zheng, Y., Dhar, R.K., O’Connell, S., Hoque, M.A., Aziz, Z., Shamsudduhin, M., Seddique, A.A., Ahmed, K.M., 2004. Decoupling of As and Fe release to Bangladesh groundwater under reducing conditions. Part I: Evidence from sediment profiles. Geochimica et Cosmochimica Acta 68, 3459-3473.

Islam, F.S., Gault, A.G., Boothman, C., Polya, D.A., Charnock, J.M., Chatterjee, D., Lloyd, J.R., 2004. Direct evidence of arsenic release from Bengal sediments mediated by indigenous metalreducing bacteria. Nature $430,68-71$. 
Jaffé, R., Mead, R., Hermandez, M.E., Peralba, M.C., DiGuida, O.A., 2001. Origin and transport of sedimentary and organic matter in two subtropical estuaries: a comparative biomarker based study. Organic Geochemistry 32, 507-526.

Kim, H.Y., Salem, N. Jr., 1990. Separation of lipid classes by solid phase extraction. Journal of Lipid Research 31, 2285-2289.

Lawati, W.M.A., Rizoulis, A., Eiche, E., Boothman, C., Polya, D.A., Lloyd, J.R., Berg, M., Aguilar, P.V., van Dongen, B.A., 2012a. Characterization of organic matter and microbial communities in contrasting arsenic-rich Holocene and arsenic-poor Pleistocene aquifers, Red River Delta, Vietnam. Applied Geochemistry 27, 315-325.

Lawati, W.M.A., Jean, J.S., Kulp, T.R., Lee, M.K., Polya, D.A., Liu, C.C., van Dongen, B.A., 2012b.Characterization of organic matter associated with groundwater arsenic in reducing aquifers of southwestern Taiwan. Journal of Hazardous Material 262, 970-979.

Lawson, M., Polya, D.A., Boyce, A.J., Bryant, C., Mondal, D., Shantz, A., Ballentine, C.J., 2013. Pond-derived organic carbon driving changes in arsenic hazard found in Asian groundwaters. Environmental Science and Technology 47, 7085-7094.

Lipid library, 2011. http://lipidlibrary.aocs.org/ms/arch_xyz/index.htm\#tmse.

Lindsay, J.F., Holliday, D.W., Hulbert, A.G., 1991. Sequence stratigraphy and the evolution of the Ganges-Brahmaputra Delta complex. American Association of Petroleum Geologists Bulletin 75, 1233-1254.

López-Sánchez, J.F., Sahuquilloa, A., Fiedlera, H.D., Rubioa, R., Raureta, G., Muntaub, H., Quevauviller, P., 1998. CRM 601, A stable material for its extractable content of heavy metals. Analyst 123, 1675-1677.

Matsuda, H., Koyama, T., 1977. Early diagenesis of fatty acids in lacustrine sediments - I. Identification and distribution of fatty acids in recent sediment from a freshwater lake. Geochimica et Cosmochimica Acta 41, 777-783.

McArthur, J.M., Ravenscroft, P., Safiullah, S., Thirlwall, M.F., 2001. Arsenic in groundwater: testing pollution mechanisms for sedimentary aquifers in Bangladesh. Water Resources Research 37, 109-117.

McArthur, J.M., Banerjee, D.M., Hudson-Edwards, K.A., Mishrab, R., Purohit, R., Ravenscroft, P., Cronine, A., Howartha, R.J., Chatterjee, A., Talukder, T., Lowryg, D., Houghtona, S., Chadha, D.K., 2004. Natural organic matter in sedimentary basins and its relation to arsenic in anoxic ground water: the example of West Bengal and its worldwide implications. Applied Geochemistry 19, 1255-1293.

Meyers, P.A., Ishiwatari, R., 1993. Lacustrine organic geochemistry man overview of indicators of organic matter sources and diagenesis in lake sediments. Organic Geochemistry 20, 867-900. 
Meyers, P.A., 1997. Organic geochemical proxies for paleoceanographic, paleolimnologic and paleoclimatic processes. Organic Geochemistry 27, 213-250.

Milici, R.C., Warwick, P.D., Attansai, E., Wandrey, C.J., 2002. To sell or not sell: assessments of Bangladesh hydrocarbons. Oil and Gas Journal 100, 24-28.

Nickson, R.T., McArthur, J., Burgess, W., Ahmed, K.M., Ravenscroft, P., Rahman, M., 1998.Arsenic poisoning of Bangladesh groundwater. Nature 395, 338.

Nickson, R.T., McArthur, J.M., Ravenscroft, P., Burgess, W.B., Ahmed, K.Z., 2000. Mechanism of arsenic release to groundwater in Bangladesh and West Bengal. Applied Geochemistry 15, 403-413.

Oremland, R.S., Stolz, J.F., 2003. The ecology of arsenic. Science 300, 939-944.

Oremland, R.S., Stolz, J.F., 2005. Arsenic, microbes and contaminated aquifers. Trends in Microbiology 13, 45-49.

Peters, K.E., Walters, C.C., Moldowan, J.M., 2005. The Biomarker Guide, Biomarkers in Petroleum Exploration and Earth History, $2^{\text {nd }}$ ed. Cambridge University Press, UK, vol. 2, pp. 645-705.

Philip, R.P.,1985. Fossil fuel biomarkers. Applications and spectra. Methods in Geochemistry and Geophysics, Elsevier, Amsterdam.

Postma, D., Larsen, F., Minh Hue, N.T., Duc, M.T., Viet, P.H., Nhan, P.Q., Jessen, S.,2007. Arsenic in groundwater of the Red River floodplain, Vietnam: Controlling geochemical processes and reactive transport modeling. Geochimica et Cosmochimica Acta 71, 5054-5071.

Quemeneur, M., Salmeron, H.A., Muller, D., Lievremont, D., Jauzein, M., Bertin, P.N., Garrido, F., Joulian, C.,2008. Diversity surveys and evolutionary relationships of aoxB genes in aerobic arsenite-oxidizing bacteria. Applied and Environmental Microbiology 74, 4567-4573.

Quevauviller, P., Rauret, G., López-Sánchez, J.F., Rubio, R., Ure, A., Muntau, H., 1997. Certification of trace metal extractable contents in a sediment reference material (CRM 601) following a three-step sequential extraction procedure. Science of Total Environment 205, 223234.

Rauret, G., López-Sánchez, J.F., Sahuquillo, A., Muntau, H., Quevauviller, PH., 2000. Indicative values for extractable contents (Mass Fractions) of $\mathrm{Cd}, \mathrm{Cr}, \mathrm{Cu}, \mathrm{Ni}, \mathrm{Pb}$ and $\mathrm{Zn}$ in sediment (CRM 601) following the modified BCR-Sequential Extraction (Three-step) Procedure (Addendum to Report 17554 EN) EUR 19502 EN. European Commission BCR Information Reference Materials, Luxembourg. 
Ravenscroft, P., Brammer, H., Richards, K., 2009.Arsenic Pollution - A Global Synthesis. Wiley-Blackwell, Chichester, UK.

Routh, J., Hjelmquist, P., 2011. Distribution of arsenic and its mobility in shallow aquifer sediments from Ambikanagar, West Bengal, India. Applied Geochemistry 26, 505-515.

Routh, J., Gustaf, H., Kuhry, P., Filley, T., Tillman, P.K., Becher, M., Crill, P.M., 2013. Multiproxy study of soil organic matter dynamics in permafrost peat deposits reveal vulnerability to climate change in the European Russian Arctic. Chemical Geology 368, 104-117.

Rowland, H.A.L., Polya, D.A., Lloyd, J.R., Pancost, R.D., 2006.Characterization of organic matter in a shallow, reducing, arsenic-rich aquifer, West Bengal. Organic Geochemistry 37, 1101-1114.

Rowland, H.A.L., Pederick, R.L., Polya, D.A., Pancost, R.D., van Dongen, B.E., Gault, A.G., Vaughan, D.J., Bryant, C., Anderson, B., Lloyd, J.R., 2007. The control of organic matter on microbially mediated iron reduction and arsenic release in shallow alluvial aquifers, Cambodia. Geobiology 5, 281-292.

SIS, 1993 Swedish Standard Method SS 0281 50.Vattenundersökningar - Bestämning av metaller med atom absorptions spektrometri i flamma - Allmänna principer och regler (Translatedtitle - Water analyses - Metal analyses by flame atomic absorption spectroscopy Principles and methods).

Smedley, P.L., Kinniburgh, D.G., 2002. A review of the source, behavior and distribution of arsenic in natural waters. Applied Geochemistry 17, 517-568.

Statistical Handbook, 2010. Statistical Database of Districts of West Bengal. Bureau of Applied Statistics, Government of West Bengal, India.

Stollenwerk, K.G., Breit, G.N., Welch, A.H., Yount, J.C., Whitney, J.W., Forster, A.L., Uddin, M.N., Majumder, R.K., Ahmed, N., 2007. Arsenic attenuation by oxidized sediments in Bangladesh. Science of Total Environment 379, 133-50.

Tuccillo, M.E., Cozzarelli, I.M., Herman, J.S., 1999. Iron reduction in the sediments of a hydrocarbon contaminated aquifer. Applied Geochemistry 14, 655-667.

Tucker, M.E., 1991. Sedimentary Petrology second ed. Blackwell Science, UK, pp. 260.

Uddin, A., Lundberg, N., 1998 Cenozoic history of the Himalayan-Bengal system: Sand composition in the Bengal basin, Bangladesh. Geological Society of America Bulletin 110, 497511.

Uddin, A., Lundberg, N., 1999. A paleo-Brahmaputra ? Subsurface litho facies analysis of Miocene deltaic sediments in the Himalayan-Bengal system, Bangladesh. Sedimentary Geology 123, 239-254. 
808 Umitsu, M., 1993. Late Quaternary sedimentary environments and landforms in the Ganges 809 Delta. Sedimentary Geology 83, 177-186.

810

811 Volkman, J.K., 1986. Review of sterol markers for marine and terrigenous organic matter.

812 Organic Geochemistry 9, 83-99.

813

814 Volkman, J.K., Barret, S.M., Blackburn, S.I., 1999. Eustigmatophyte microalgae are potential 815 sources of C29 sterol, C22-C28 n-alcohols and C28-C32 n-alkyl diols in freshwater 816 environments. Organic Geochemistry 30, 307-318.

818 von Brömssen, M., Larsson, S.H., Bhattacharya, P., Hasan, M.A., Ahmed, K.M., Jakariya, M., 819 Sikder, M.A., Sracek, O., Biven, A., Doušouvá, B., Patricia, C., Thunvik, R., Gunnar, J., 2008. 820 Geochemical characterization of shallow aquifer sediments of Matlab Upazila, Southeastern 821 Bangladesh - implications for targeting low-As aquifers. Journal of Contaminant Hydrology 99, 822 137-49.

823

824 Westerhausen, L., Poynter, J., Eglinton, G., Erlenkeuser, H., and Sarnthein, M., 1993. Marine 825 and terrigenous origin of organic matter in modern sediments of the equatorial East Atlantic: the $826 \quad \delta^{13} \mathrm{C}$ and molecular record. Deep Sea Research Part I 40, 1087-1121. 


\section{Table and figure captions}

831 Table 1. Scheme of BCR sequential extraction protocol of elements from sediment

832 Table 2. Comparison of trace element concentrations in the CRM-601 standard obtained in this 833 study with the original certified values reported by López-Sánchez et al. (1998)

834 Table 3. Correlation of As with other elements in the four different sediment geochemical 835 fractions in Haringhata, West Bengal.

836 Table 4. Rotated Component Matrix for organic and inorganic variables distributed along the 837 vertical sedimentary profile

838

839

Fig. 1. Location of the BSA well investigated in Haringhata, Nadia district, West Bengal, India.

840 Fig. 2. Downcore distribution of total organic carbon with respect to sediment grain size in 841 Haringhata BSA well.

842 Fig. 3. Distribution of elements in different geochemical fractions in BSA sediments in 843 Haringhata, West Bengal. Metal concentrations are plotted versus depth (m).

844 Fig. 4. Distribution of various lipid fractions and their ratios in BSA sediments in Haringhata.

845 Fig. 5. Component plot in rotated space, circles showing the aggregated loadings defined by each 846 principal component.

847 Fig. 6. Predictor space plot showing As, Fe and fatty acid as selected predictors.

848

849 Supplementary Data

850 Table S1 Detection limits of different elements in matrix in four different fractions (in $\mu \mathrm{g} / \mathrm{l}$ )

851

852 Table S2. Distribution of different lipid fractions along the vertical sedimentary profile in 853 Haringhata BSA.

854

855 Fig. S1. Relative abundance of As, Fe and $\mathrm{Mn}$ in the four fractions extracted from BSA 856 sediments with BCR protocol.

857

858 
Table 1

860

861

\begin{tabular}{|l|l|l|}
\hline Fractions & Extracted with & Target phases $^{\mathbf{a}}$ \\
\hline 1 & $20 \mathrm{ml}, 0.11 \mathrm{M}$ Acetic acid, shaken for 16 h & $\begin{array}{l}\text { Carbonates (pH sensitive), including elements participating in } \\
\text { sorption and desorption ion exchange processes in soluble phase. }\end{array}$ \\
\hline 2 & $\begin{array}{l}20 \mathrm{ml}, 0.5 \mathrm{M} \text { Hydroxylamine hydrochloride, } \\
\mathrm{pH} 1.5, \text { shaken for } 16 \mathrm{~h}\end{array}$ & Oxides sensitive to change in pE. \\
\hline 3 & $\begin{array}{l}5 \mathrm{ml}, 8.8 \mathrm{M} \text { Hydrogen peroxide, } \mathrm{RT}, 1 \mathrm{~h} . \\
\text { At } 85^{\circ} \mathrm{C}, 1 \mathrm{~h} . \\
5 \mathrm{ml}, 8.8 \mathrm{M} \text { Hydrogen peroxide, } 85^{\circ} \mathrm{C}, 1 \mathrm{~h} . \\
25 \mathrm{ml}, 1.0 \mathrm{M} \text { Ammonium acetate, } \mathrm{pH} 2.0, \\
\text { shaken for } 16 \text { hours. }\end{array}$ & Sulfides and organic matters \\
& $\begin{array}{l}10 \mathrm{ml}, 7 \mathrm{M} \text { Nitric acid, at } 121^{\circ} \mathrm{C}, 100 \mathrm{kPa} \\
\text { for } 30 \mathrm{mins}\end{array}$ & Pseudo total content including silicate and crystalline residuals \\
\hline 4
\end{tabular}

862

a Quevallier et al. (1997) and Rauret et al. (2000).

b SIS (1993).

864

$\mathrm{RT}$ is room temperature

865 
Table 2

867

868

\begin{tabular}{|c|c|c|c|c|c|c|c|c|c|c|c|c|c|c|c|}
\hline \multirow[t]{2}{*}{ Elements } & \multicolumn{5}{|c|}{ Step 1} & \multicolumn{5}{|c|}{ Step 2} & \multicolumn{5}{|c|}{ Step 3} \\
\hline & $\begin{array}{l}\text { BCR } \\
(2000)^{*}\end{array}$ & $\begin{array}{l}\text { Present } \\
\text { study }^{*}\end{array}$ & $\begin{array}{l}\text { SD } \\
\text { values }\end{array}$ & $\begin{array}{l}95 \% \\
\text { confidence }\end{array}$ & $\begin{array}{l}\text { Within } \\
\text { confidence }\end{array}$ & $\begin{array}{l}\text { BCR } \\
(2000)^{*}\end{array}$ & $\begin{array}{l}\text { Present } \\
\text { study }^{*}\end{array}$ & $\begin{array}{l}\text { SD } \\
\text { values }\end{array}$ & $\begin{array}{l}95 \% \\
\text { confidence }\end{array}$ & $\begin{array}{l}\text { Within } \\
\text { Confidence }\end{array}$ & $\begin{array}{l}\text { BCR } \\
(2000)\end{array}$ & $\begin{array}{l}\text { Present } \\
\text { study }^{*}\end{array}$ & $\begin{array}{l}\text { SD } \\
\text { values }\end{array}$ & $\begin{array}{l}95 \% \\
\text { confidence }\end{array}$ & $\begin{array}{l}\text { Within } \\
\text { Confidence }\end{array}$ \\
\hline Cd & 4.46 & 4.04 & 0.63 & 1.23 & YES & 3.05 & 3.65 & 0.53 & 1.03 & YES & 1.80 & 1.53 & 0.17 & 0.33 & YES \\
\hline $\mathrm{Cr}$ & 0.37 & 0.22 & 0.08 & 0.16 & YES & 1.42 & 5.31 & 0.90 & 1.76 & NO & 19.4 & 19.9 & 0.91 & 1.78 & YES \\
\hline $\mathbf{C u}$ & 10.4 & 14.7 & 0.43 & 0.84 & NO & 6.37 & 51.4 & 4.90 & 9.60 & NO & 116 & 120 & 9.00 & 17.6 & YES \\
\hline $\mathrm{Ni}$ & 8.22 & 4.99 & 0.83 & 1.62 & $\mathrm{NO}$ & 5.55 & 8.73 & 1.20 & 2.35 & YES & 6.75 & 10.3 & 0.86 & 1.68 & $\mathrm{NO}$ \\
\hline $\mathbf{P b}$ & 2.07 & 1.25 & 0.49 & 0.96 & YES & 37.3 & 142 & 11.0 & 21.5 & NO & 108 & 58.7 & 19.0 & 37.2 & NO \\
\hline $\mathbf{Z n}$ & 259 & 206 & 13.0 & 25.4 & NO & 175 & 214 & 17.0 & 33.3 & NO & 124 & 177 & 17.0 & 33.3 & NO \\
\hline
\end{tabular}

869

*Trace metal concentration in $\mathrm{mg} / \mathrm{kg}$

870

871

872

873

874

875

876

877

878

879

880 
881 Table 3

882

\begin{tabular}{|c|c|c|c|c|c|c|c|c|c|c|c|c|c|c|c|}
\hline & & $\mathbf{F e}$ & Mn & $\mathbf{P}$ & $\mathrm{Ni}$ & $\mathrm{Cu}$ & Zn & $\mathbf{P b}$ & Cd & $\mathrm{Na}$ & Mo & $\mathrm{Cr}$ & $\mathbf{V}$ & Ca & Mg \\
\hline \multirow[t]{2}{*}{ Fraction 1} & $\begin{array}{l}\text { Pearson } \\
\text { Correlation }\end{array}$ & $0.586^{* *}$ & -0.125 & $0.948^{* *}$ & $0.734^{* *}$ & $0.548^{*}$ & $0.562^{* *}$ & -0.274 & 0.052 & -0.001 & $0.774^{* *}$ & $0.770^{* *}$ & $0.706^{* *}$ & -0.321 & -0.154 \\
\hline & Sig. (2-tailed) & 0.007 & 0.598 & 0.000 & 0.000 & 0.012 & 0.010 & 0.242 & 0.829 & 0.996 & 0.000 & 0.000 & 0.001 & 0.168 & 0.518 \\
\hline \multirow[t]{2}{*}{ Fraction 2} & $\begin{array}{l}\text { Pearson } \\
\text { Correlation }\end{array}$ & 0.090 & -0.034 & $0.460^{*}$ & -0.064 & 0.074 & 0.017 & 0.035 & 0.219 & 0.006 & -0.113 & -0.084 & 0.179 & -0.331 & -0.413 \\
\hline & Sig. (2-tailed) & 0.705 & 0.887 & 0.041 & 0.789 & 0.758 & 0.942 & 0.882 & 0.355 & 0.980 & 0.635 & 0.725 & 0.451 & 0.154 & 0.070 \\
\hline \multirow[t]{2}{*}{ Fraction 3} & $\begin{array}{l}\text { Pearson } \\
\text { Correlation }\end{array}$ & $0.759^{* *}$ & 0.152 & 0.428 & $0.640^{* *}$ & $0.750^{* *}$ & 0.280 & $0.804^{* *}$ & $0.775^{* *}$ & $0.773^{* *}$ & 0.154 & $0.756^{* *}$ & 0.290 & 0.271 & 0.295 \\
\hline & Sig. (2-tailed) & 0.000 & 0.522 & 0.060 & 0.002 & 0.000 & 0.233 & 0.000 & 0.000 & 0.000 & 0.516 & 0.000 & 0.215 & 0.247 & 0.206 \\
\hline \multirow[t]{2}{*}{ Fraction 4} & $\begin{array}{l}\text { Pearson } \\
\text { Correlation }\end{array}$ & $0.790^{* *}$ & $0.587^{* *}$ & 0.204 & $0.763^{* *}$ & $0.846^{* *}$ & $0.809^{* *}$ & $0.877^{* *}$ & $0.800^{* *}$ & 0.438 & $0.849^{* *}$ & $0.728^{* *}$ & $0.685^{* *}$ & -0.288 & $0.690^{* *}$ \\
\hline & Sig. (2-tailed) & 0.000 & 0.007 & 0.388 & 0.000 & 0.000 & 0.000 & 0.000 & 0.000 & 0.054 & 0.000 & 0.000 & 0.001 & 0.218 & 0.001 \\
\hline
\end{tabular}

883

*Correlation is significant at the 0.05 level (2-tailed).

$884{ }^{* *}$ Correlation is significant at the 0.01 level (2-tailed). 
Table 4

888

\begin{tabular}{|lccr|}
\hline & & Components & \\
& $\mathbf{1}$ & $\mathbf{2}$ & $\mathbf{3}$ \\
\hline Eigen value & 4.05 & 2.25 & 1.48 \\
\hline \% total variance & 40.5 & 22.5 & 14.8 \\
\hline Arsenic & $\mathbf{0 . 7 0}$ & 0.11 & -0.15 \\
Iron & $\mathbf{0 . 9 8}$ & -0.01 & -0.05 \\
Manganese & $\mathbf{0 . 9 2}$ & $-0,05$ & 0.14 \\
Phosphorus & 0.31 & $-0,18$ & $\mathbf{0 . 7 5}$ \\
Fine Sand & -0.38 & 0.14 & $\mathbf{0 . 8 5}$ \\
Silt and Clay & $\mathbf{0 . 9 3}$ & -0.17 & -0.17 \\
Alkane & 0.06 & $\mathbf{0 . 8 0}$ & -0.15 \\
Sterol & 0.04 & $\mathbf{0 . 8 6}$ & 0.04 \\
Fatty Acids & -0.08 & $\mathbf{0 . 8 7}$ & 0.07 \\
\hline
\end{tabular}

889

Extraction Method: Principal Component Analysis.

890 Rotation Method: Varimax with Kaiser Normalization.

891 Loadings $>0.5$ are in bold.

892

893 
Supplementary Table

895

Table S1

897

\begin{tabular}{|l|lllll|}
\hline Metals & Step-1 & Step-2 & Step-3 & HNO $_{3}$ & TD \\
\hline Arsenic & 0.10 & 0.10 & 0.10 & 0.10 & 0.20 \\
\hline Iron & 10.0 & 10.0 & 10.0 & 300 & 300 \\
\hline Manganese & 0.20 & 0.20 & 0.20 & 0.20 & 0.50 \\
\hline Phosphorus & 10.0 & 10.0 & 30.0 & 30.0 & 30.0 \\
\hline Cadmium & 0.10 & 0.10 & 0.10 & 0.10 & 0.20 \\
\hline Chromium & 0.10 & 0.10 & 0.10 & 0.20 & 0.20 \\
\hline Nickel & 0.10 & 0.10 & 0.10 & 0.30 & 0.30 \\
\hline Lead & 0.10 & 0.10 & 0.10 & 0.20 & 0.20 \\
\hline Zinc & 1.00 & 5.00 & 5.00 & 5.00 & 5.00 \\
\hline
\end{tabular}

898

Table S2

900

\begin{tabular}{|l|ccc|}
\hline \multirow{2}{*}{$\begin{array}{l}\text { Sample } \\
\text { depth } \\
\text { in meters }\end{array}$} & \multicolumn{3}{|c|}{$\begin{array}{c}\text { Concentration (ng/g)of different lipid } \\
\text { fractions }\end{array}$} \\
\cline { 2 - 4 } & n-alkane & n-alkanoic acid & n-alkanol \\
\hline $0-6$ & 0.53 & 1071 & 0.11 \\
\hline $6-12$ & 0.44 & 201 & 4.47 \\
\hline $12-18$ & 0.69 & 1960 & 1.15 \\
\hline $18-24$ & 0.63 & 2220 & 5.31 \\
\hline $24-30$ & 1.16 & 5194 & 5.67 \\
\hline $30-36$ & 0.78 & 6031 & 6.20 \\
\hline $36-42$ & 0.96 & 1246 & 9.41 \\
\hline $42-48$ & 0.66 & 1088 & 0.05 \\
\hline $48-54$ & 0.89 & 930 & 0.27 \\
\hline $54-60$ & 0.05 & 885 & 1.10 \\
\hline $60-66$ & 0.09 & 1409 & 1.04 \\
\hline $66-72$ & 0.12 & 839 & 1.38 \\
\hline $72-78$ & 0.19 & 504 & 0.99 \\
\hline $78-84$ & 0.12 & 600 & 0.02 \\
\hline $84-90$ & 0.06 & 494 & 0.34 \\
\hline $90-96$ & 0.13 & 441 & 0.94 \\
\hline $96-102$ & 0.12 & 390 & 0.07 \\
\hline $102-108$ & 0.17 & 372 & 0.93 \\
\hline $108-112$ & 0.14 & 365 & 0.62 \\
\hline $112-118$ & 0.09 & 549 & 1.17 \\
\hline $118-124$ & 0.09 & 768 & 0.68 \\
\hline $124-130$ & 0.04 & 307 & 3.09 \\
\hline $130-136$ & 0.20 & 3794 & 3409 \\
\hline $136-142$ & 0.54 & 1674 & 4932 \\
\hline $142-148$ & 25.1 & & \\
\hline $148-154$ & 0.38 & & \\
\hline
\end{tabular}




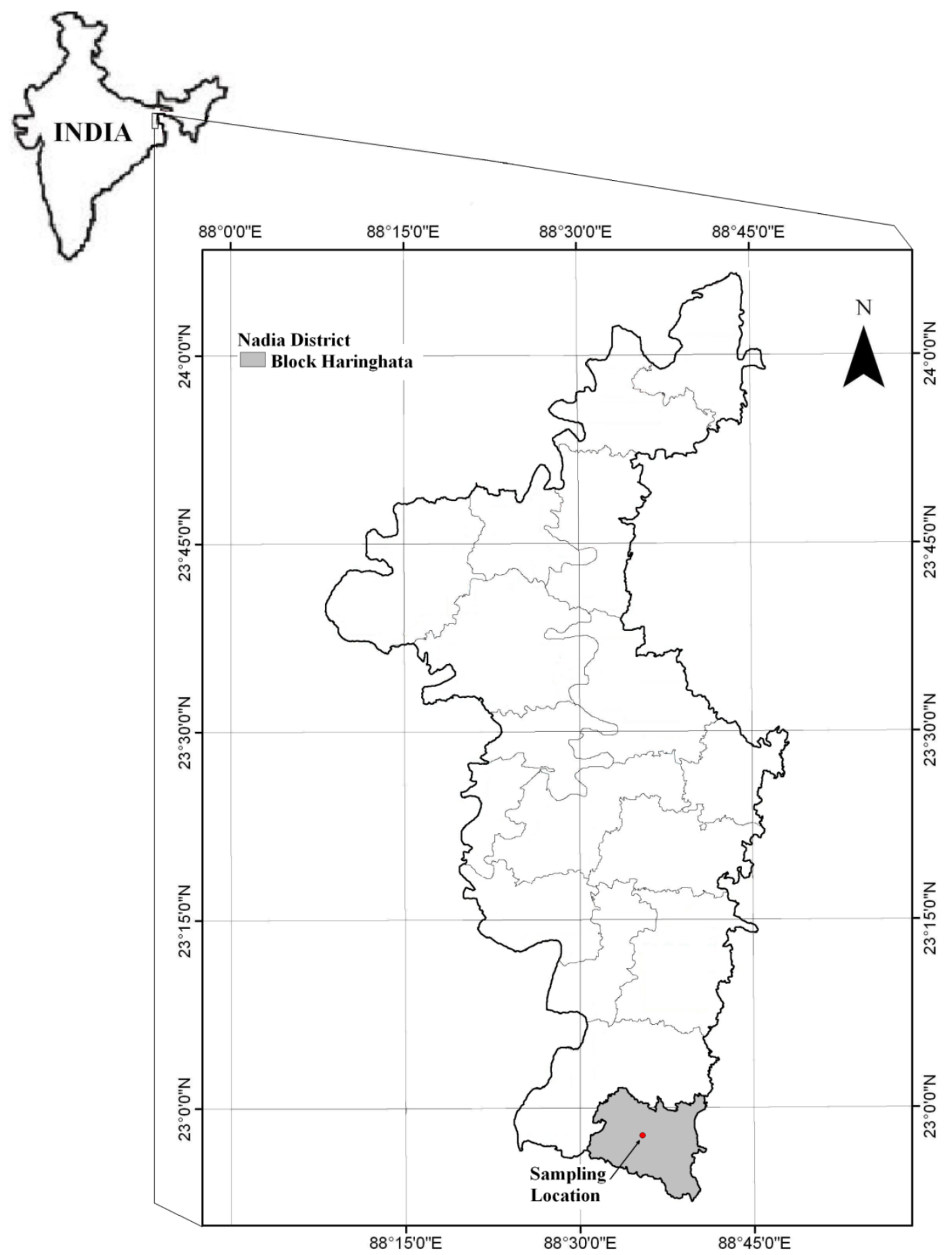

901

Fig. 1. 


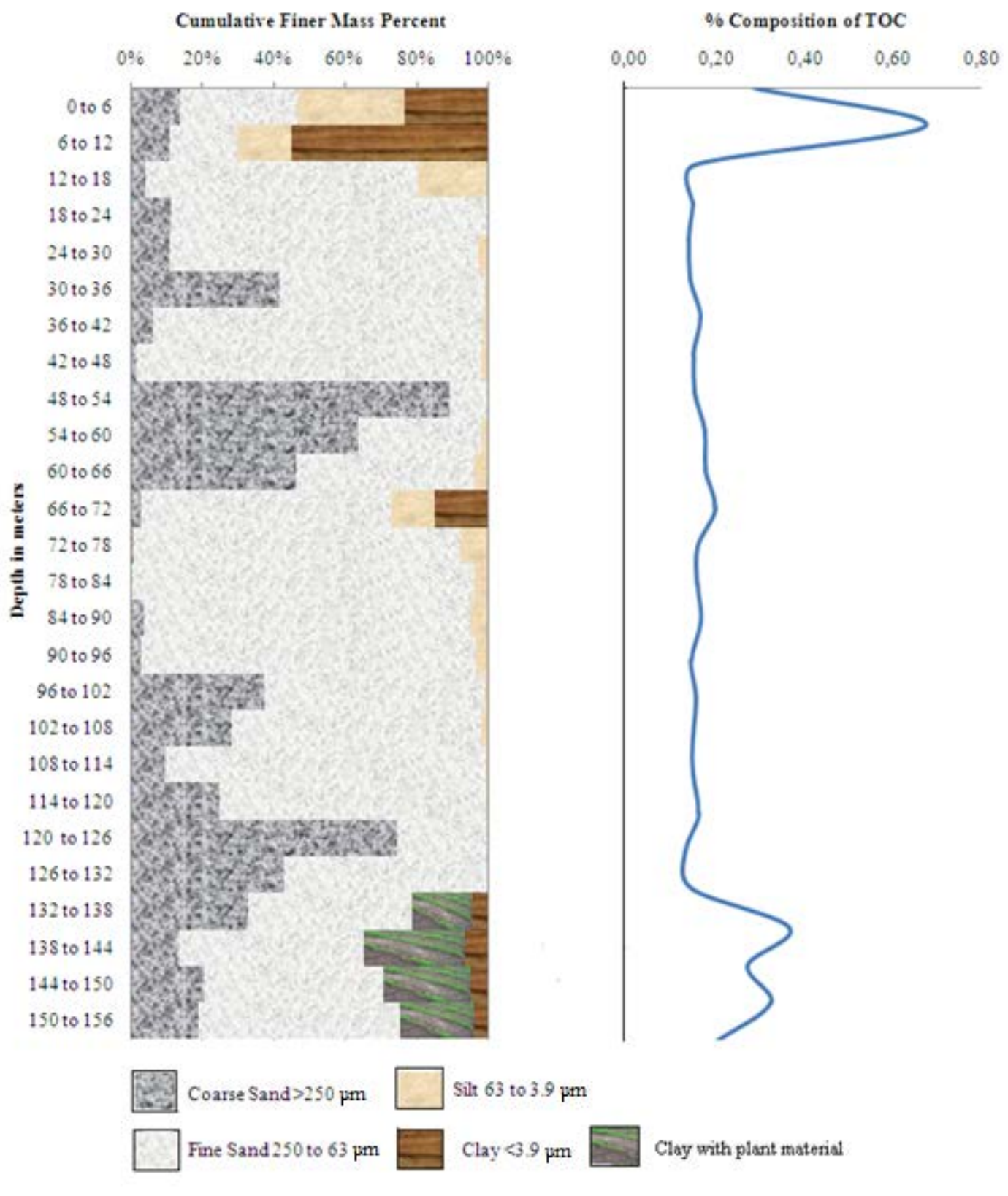

Fig. 2. 
Concentration of Element* in $\mathrm{mg} / \mathrm{kg}$ of sediment

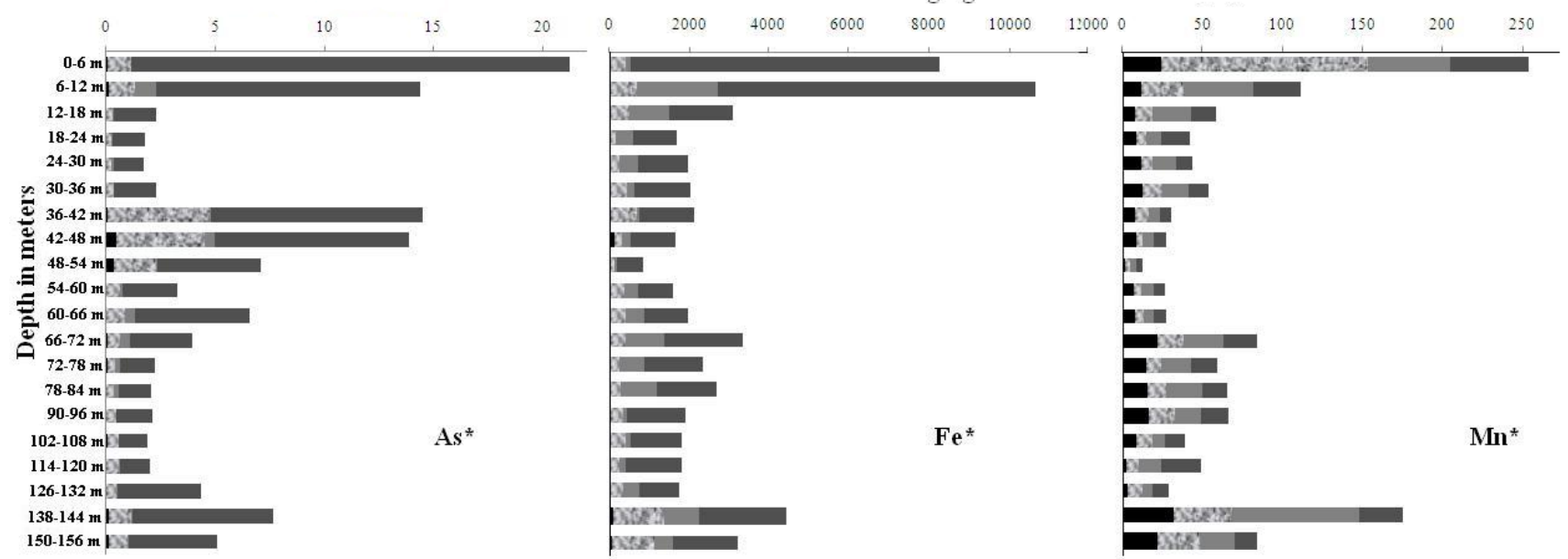

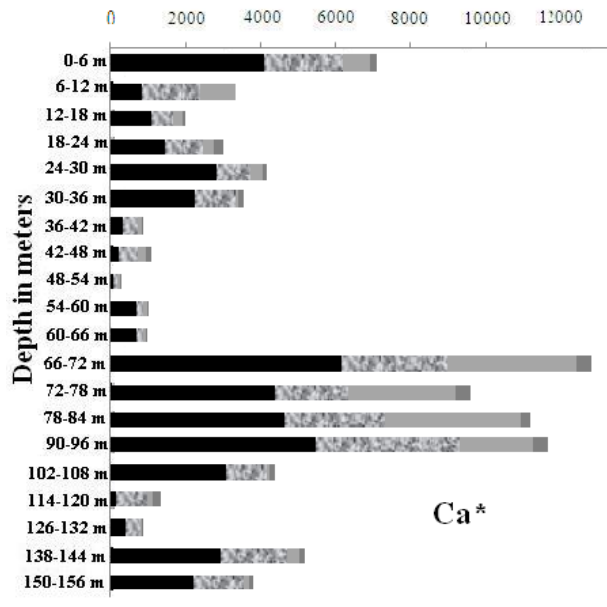

Fraction 1 (Carbonates)

Fraction 3 (OM, Sulfides)
Concentration of Element* in mg/kg of sediment

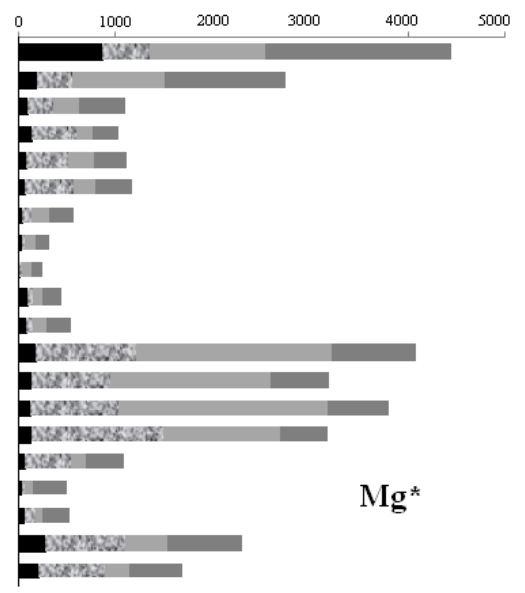

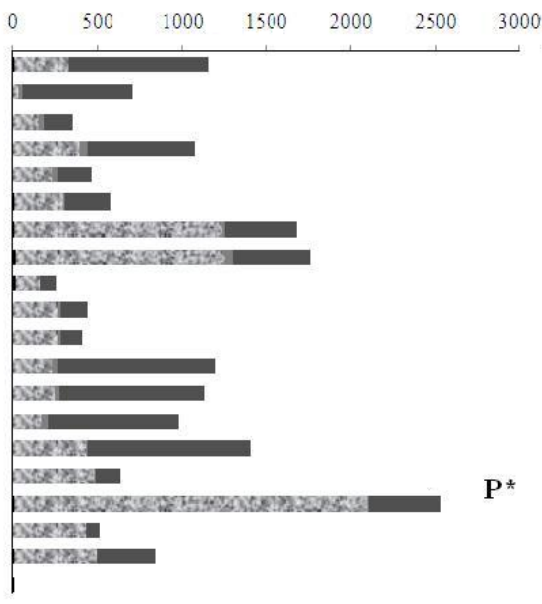

Fraction 2 (Oxides)

Frcation 4 (Residuals)

Fig. 3. 


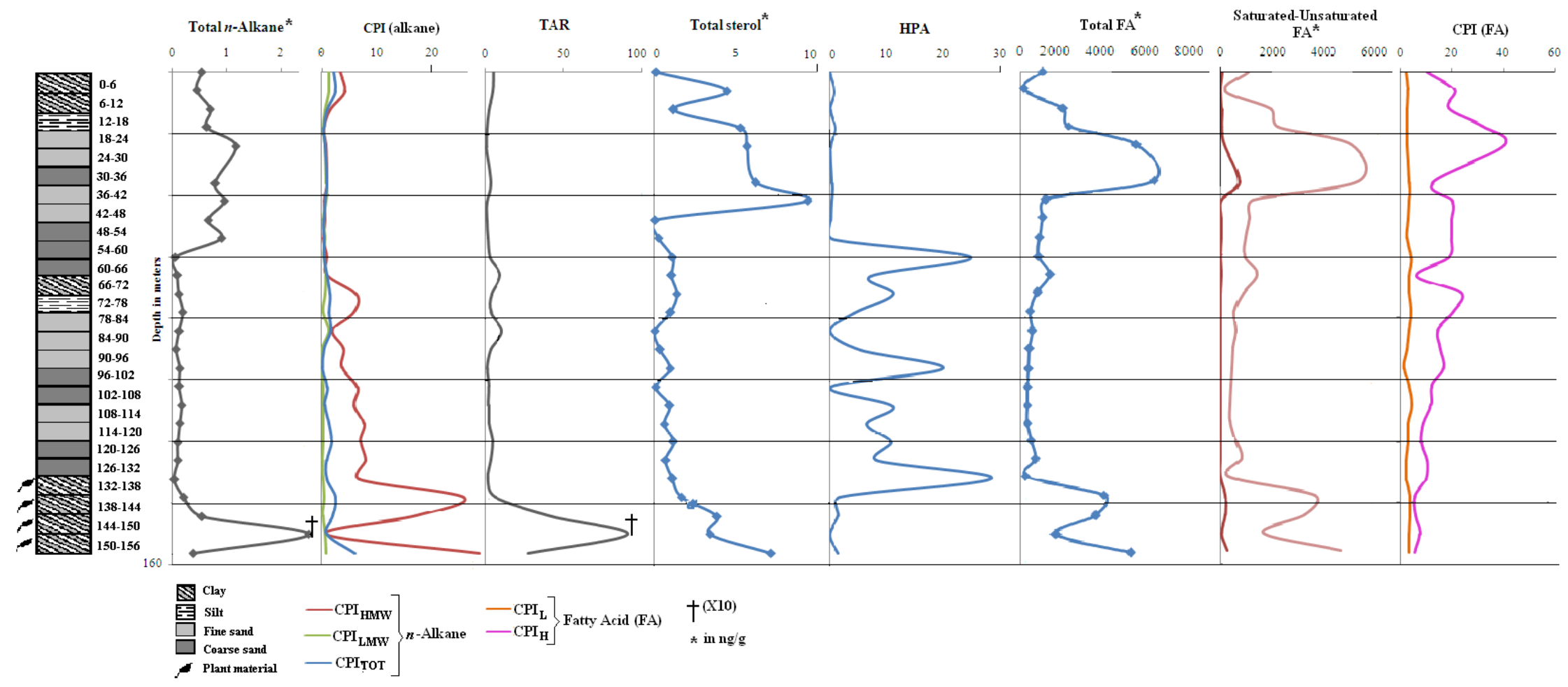

914

915 The dots on the curve represent the absolute concentration of biomarkers.

916

917 Fig. 4.

918

919

920

921

922

923

35 
924

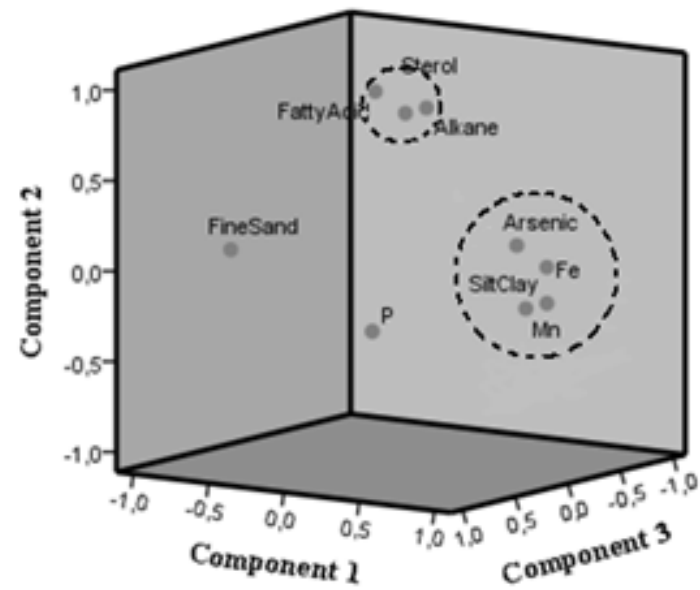

925 Fig. 5.

926

927

928 


\section{Predictor Space}

Built Model: 3 selected predictors, $K=3$

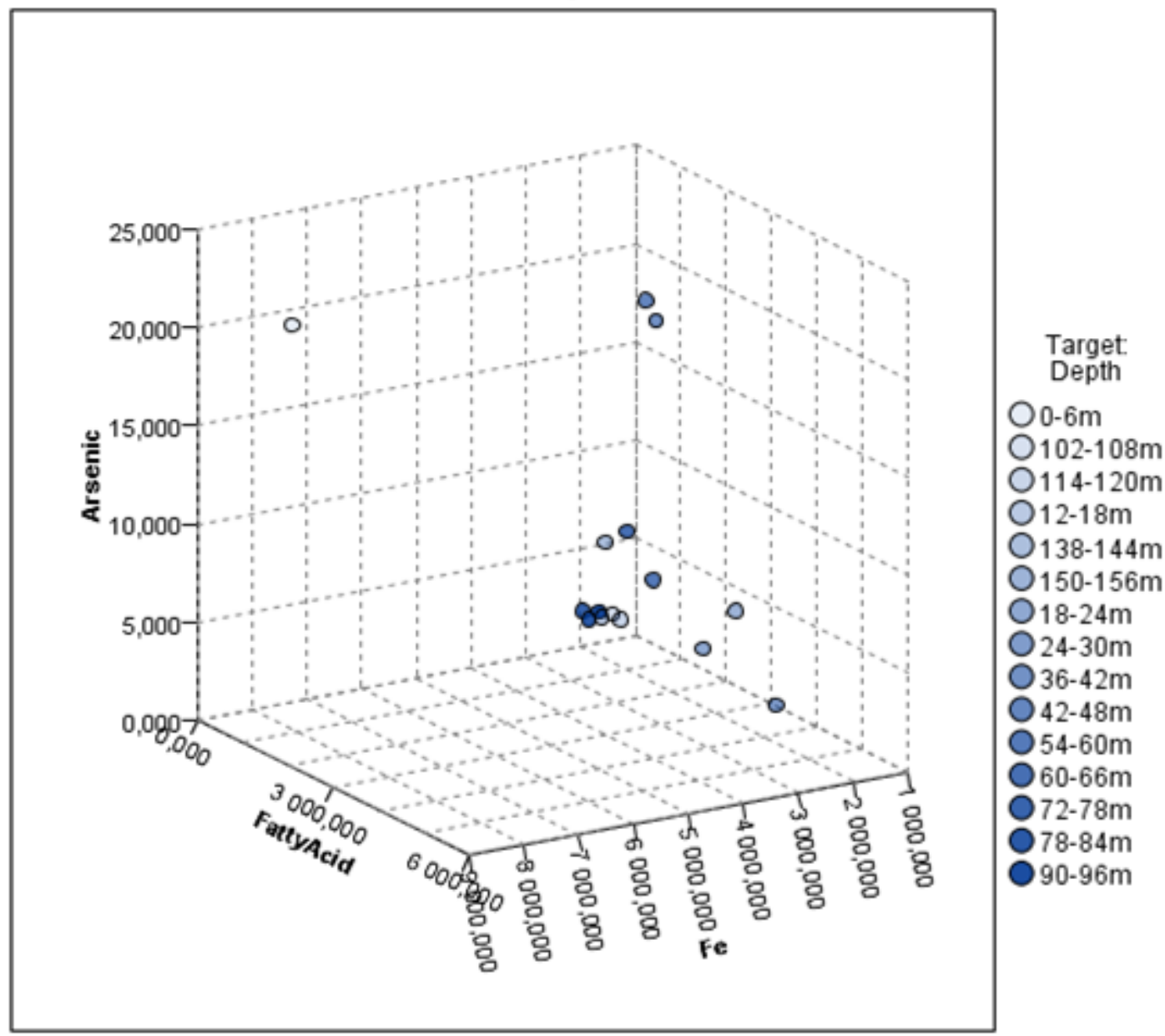

931

932

933 Fig. 6.

934 


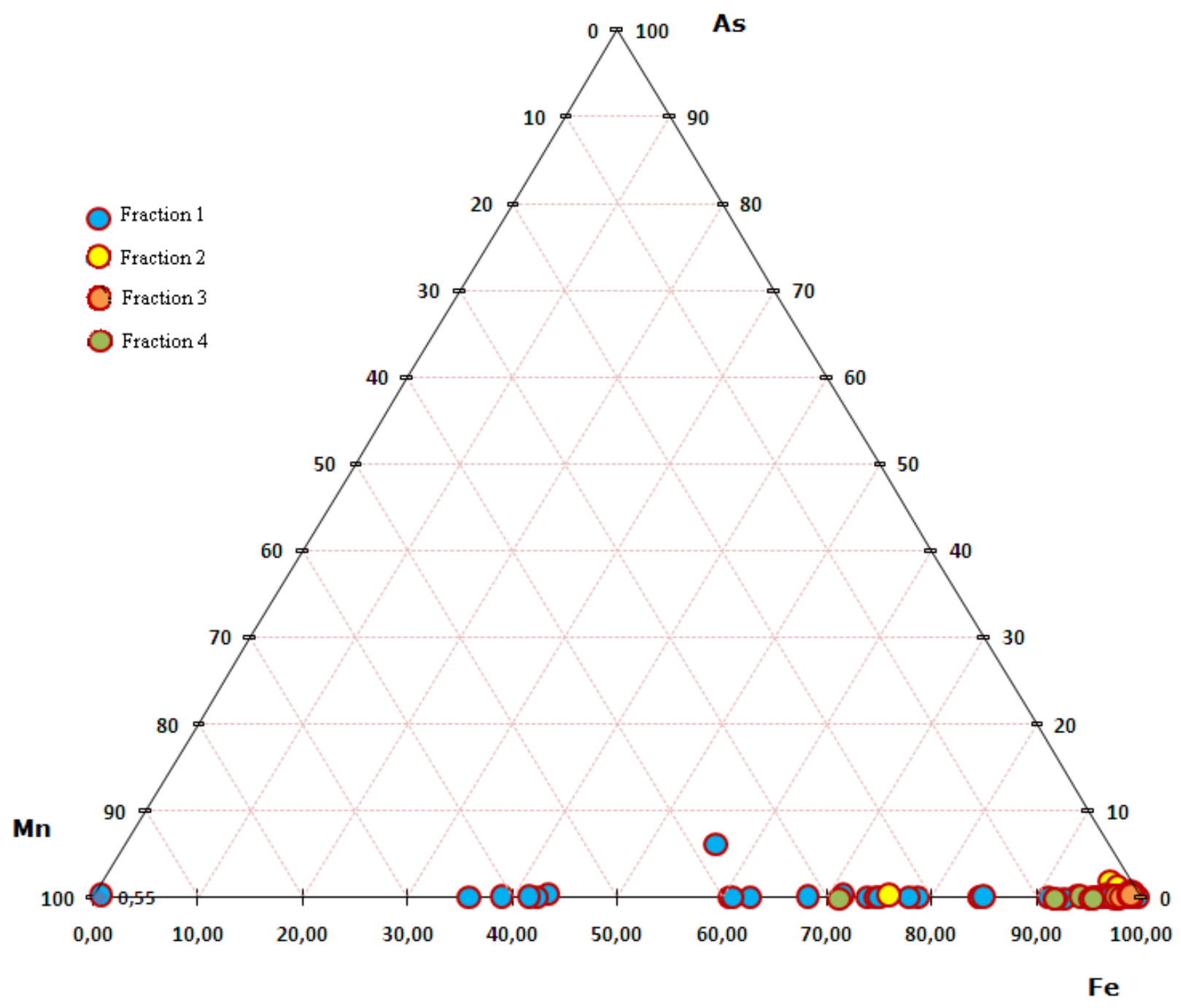

935

936 Fig. S1.

937

938 